\title{
Turmeric and Chinese goldthread synergistically inhibit prostate cancer cell proliferation and NF-kB signaling
}

\author{
Yi Zhao ${ }^{1}$, J. Jason Collier ${ }^{1 *}$, E-Chu Huang ${ }^{1}$ and Jay Whelan ${ }^{1,2}$ \\ ${ }^{1}$ Department of Nutrition, 229 Jessie Harris Building, and ${ }^{2}$ Tennessee Agricultural Experiment \\ Station, University of Tennessee, Knoxville, TN 37996, USA
}

Corresponding Author: Jay Whelan, Department of Nutrition, Laboratory for Cancer Research, 1215 West Cumberland Avenue, Room 229 Jessie Harris Building, University of Tennessee, Knoxville, TN 37996-1920, USA

Submission date: June 10, 2014; Acceptance date: July 16, 2014; Publication date: July 21, 2014

\begin{abstract}
:
Background: Pre-clinical studies using bioactive compounds from botanicals appear to offer some protection against cancer. Research using single bioactives contributes greatly to our understanding of their mechanism of action, but in vitro studies demand concentrations that are higher than achievable in humans $(\mu \mathrm{M})$. However, maintaining these bioactives in the presence of other compounds originally derived from the food or extract of origin may synergistically lower the bioactive dose so translatability becomes feasible. The objective of this study was to determine if bio-efficacy of phytonutrients can be enhanced when used in combination even at doses that are ineffective for any compound when used in isolation.
\end{abstract}

Methods: The anti-proliferative and molecular effects of herbs (turmeric and Chinese goldthread) and their bioactives (curcumin and ar-turmerone, berberine and coptisine, respectively) were determined in isolation and in combination. Using CWR22Rv1 and HEK293 cells, cell proliferation (as assessed by the MTT assay) and NF- $\kappa$ B promoter activity (using a luciferase reporter construct) were evaluated and synergy of action was assessed by the ChouTalalay method utilizing CompuSyn ${ }^{\circledR}$ software.

Results: Turmeric and Chinese goldthread act synergistically (combination index $<1$ ) when inhibiting cell proliferation with all cell lines tested. The synergy of action of combinations of companion bioactives from the same herb (i.e., curcumin/ar-turmerone and berberine/coptisine) and bioactives from different herbs (i.e., curcumin/berberine) help to explain why turmeric and Chinese goldthread are more effective than their major bioactives in isolation. At the molecule level, curcumin+ar-turmerone and curcumin+coptisine synergistically attenuated TNF $\alpha$ stimulated $\mathrm{NF}-\kappa \mathrm{B}$ promoter activity. Even compounds with poor efficacy become more biologically active in the presence of companion compounds. Importantly, the effects of 
combining any two bioactives or herbal extracts were highly synergistic at concentrations approaching physiological significance (nanomolar).

Conclusions: These results suggest that bioactives in combination (as plant extracts or isolated compounds) are highly synergistic at the cellular and molecular level at physiologically relevant concentrations. These data help to explain why complex mixtures of botanicals may be more efficacious than their bioactives in isolation.

Keywords: Synergy; Chou-Talalay; turmeric; Chinese goldthread; curcumin; berberine; arturmerone; coptisine; prostate cancer; $\mathrm{NF}-\kappa \mathrm{B}$

\section{BACKGROUND:}

Research exploring the use of natural products, such as botanicals, herbs, herbal extracts, and their isolated bioactives are becoming increasingly appealing because of their potential efficacy in attenuating growth and viability of cancer cells with few observed side effects in humans when these agents are taken orally. The combination of multiple botanicals may prove to be more efficacious as compared with their use in isolation. These effects may be related to the fact that when bioactives are used in combination, their synergy could reduce the concentration needed for effectiveness to one that is physiologic. For example, polyherbal mixtures can be quite effective in inhibiting cancer cell proliferation when individual herbal extracts have no effect (see Supplemental Figure 1). Furthermore, in vitro studies demand concentrations (often in the $20-100 \mu \mathrm{M}$ range) $[1,2]$ that are several orders of magnitude higher than $\mathrm{nM}$ concentrations achievable in humans. The difference between these effects seen in vitro using micromolar concentrations when compared with the nanomolar concentrations measured in humans raises the issue of the translational relevance of some of the in vitro studies, which likely accounts for at least part of the disappointing outcomes in clinical trials [3]. Tables 1 and 2 summarize this point where the mean $\mathrm{IC}_{50}$ concentrations observed in a variety of cancer cell lines are $41 \mu \mathrm{M}, 21$ $\mu \mathrm{M},>243 \mu \mathrm{M}$ and $29 \mu \mathrm{M}$ for the bioactives berberine, curcumin, ar-turmerone and coptisine, respectively, while the serum/plasma concentrations in humans provided oral doses of curcumin are in the nanomolar range. With one exception, the serum/plasma levels of curcumin are $<200$ $\mathrm{nM}$ at doses as high as $12 \mathrm{~g}$ (Table 2). Maintaining an individual bioactive in the presence of other bioactive compounds (originally derived from the food or extract of origin) may turn isolated compounds that have weak bioactivity to those that have substantially more activity at lower doses. This would make translation to humans more feasible. For instance, the World Cancer Research Fund/American Institute for Cancer Research reports that consumption of individual nutrients could in some instances result in vastly different outcomes when compared with their foods of origin [4]. This concept of the importance of the complex source versus isolated nutrients is echoed by the American Cancer Society [5]. Importantly, this concept can be equally applied to combinations of foods or botanicals.

To investigate the synergistic action of botanicals, we used CWR22Rv1 and HEK293 cells. CWR22Rv1 cells are an in vitro model of castrate-resistant prostate cancer (PCa) [6] and complement our research investigating the effects of a mixture of bioactive botanicals on in vitro 
Table l. In vitro antiproliferative effects of berbenine, curcumin, coptisine and ar-turmerone in a vanety of cell lines based on $\mathrm{IC}_{50}$ concentrations $(\mu \mathrm{M})$.

\begin{tabular}{|c|c|c|c|c|c|c|c|c|c|c|}
\hline \multicolumn{2}{|l|}{ Berberine [41] } & \multicolumn{3}{|l|}{ Curcumin } & \multicolumn{3}{|c|}{ ar-Turmerone } & \multicolumn{3}{|l|}{ Coptisine } \\
\hline Cell Line & $I_{0}$ & Cell Line $I_{50}$ & Ref & & Cell Line & IC: & Ref & Cell Line & $I C_{0}$ & Ref \\
\hline$\overline{\mathrm{HeLa}}$ & 20 & KBM-5 & 3.8 & {$[42]$} & MDA-MB-231 & $>100$ & {$[33]$} & MDA-MB-231 & 78 & [43] \\
\hline L1210 & 10 & Jurkat & 4.3 & {$[42]$} & & 50 & {$[34]$} & Hela & 35 & [44] \\
\hline $\mathrm{A} 431$ & 75 & U266 & 7.6 & {$[42]$} & & $>462$ & {$[35]$} & MDA-MB 468 & 63 & [43] \\
\hline DU145 & 100 & A549 & 17 & [42] & MCF-7 & $>100$ & [33] & $\mathrm{HepG2}$ & 203 & {$[45]$} \\
\hline U937 & 15 & U87 & 15 & {$[46]$} & & $>50$ & {$[34]$} & & 3.5 & {$[47]$} \\
\hline MCF7 & 20 & T98G & 31 & [46] & & $>462$ & {$[35]$} & Hep 3 B & 5.4 & [47] \\
\hline CL1.5 & 7.5 & $\mathrm{PC} 3$ & 32 & {$[48]$} & HepG2 & $>100$ & [33] & SK-Hep1 & 1.4 & {$[47]$} \\
\hline Colo205 & 80 & LNCaP & 53 & [49] & & 300 & {$[36]$} & PLCPRF/5 & 6.6 & {$[47]$} \\
\hline C6 & 10 & DU-145 & 30 & {$[50]$} & & $>462$ & {$[35]$} & K562 & 7.2 & {$[47]$} \\
\hline U.87 & 20 & MCF-7 & 20 & {$[51]$} & Hep3B & 564 & [36] & U937 & 1.5 & [47] \\
\hline VSMC & 200 & $\mathrm{MCF} 7 / \mathrm{LCC} 2$ & 20 & [51] & Huh-7 & 472 & {$[36]$} & Raï & 0.6 & [47] \\
\hline B16 & 3 & MCF 7 LCC9 & 20 & 51 & U937 & 185 & {$[52]$} & $\mathrm{P} 3 \mathrm{H} 1$ & 11 & {$[47]$} \\
\hline RPMI 8226 & 5 & Mean & 21 & & K562 & 185 & {$[32]$} & $\mathrm{L}_{0} \mathrm{~V}_{0}$ & 2.7 & [53] \\
\hline MDA-MB231 & 25 & & & & L1210 & 116 & {$[32]$} & $\mathrm{L}_{0} \mathrm{~V}_{0} / \mathrm{Dx}$ & 12.5 & [53] \\
\hline NPC-HK1 & 200 & & & & U937 & 111 & {$[32]$} & HT29 & 1.5 & {$[53]$} \\
\hline $\mathrm{EAC}$ & 2 & & & & $\mathrm{RB} 1-2 \mathrm{H} 3$ & 162 & {$[32]$} & Mean & 29 & \\
\hline YES-6 & 3 & & & & Mean & & $>243$ & & & \\
\hline NIH-3T3 & 30 & & & & & & & & & \\
\hline $\mathrm{A} 7 \mathrm{r} 5$ & 23 & & & & & & & & & \\
\hline HepG2 & 39 & & & & & & & & & \\
\hline Hep3B & 45 & & & & & & & & & \\
\hline Sk-Hepl & 10 & & & & & & & & & \\
\hline PLCPRF/5 & 40 & & & & & & & & & \\
\hline K562 & 43 & & & & & & & & & \\
\hline U937 & 28 & & & & & & & & & \\
\hline P3H1 & 24 & & & & & & & & & \\
\hline Raji & 1.8 & & & & & & & & & \\
\hline$\underline{1929}$ & 120 & & & & & & & & & \\
\hline Mean & 41 & & & & & & & & & \\
\hline
\end{tabular}

and in vivo models of castrate-resistant PCa [7-9]. The HEK293 cell line is a transformed human embryonic kidney cell that is widely used as a tool for expression vectors [10]. In this case, HEK293 cells were transfected with a recombinant plasmid expressing a luciferase gene under the control of a multimerized NF- $\kappa \mathrm{B}$ responsive-promoter stimulated with TNF $\alpha$ [11].

In Traditional Chinese Medicine [12], Chinese goldthread and turmeric are used in combination to treat a variety of diseases, among them cancer. Cancer has been explained as a combination of damp-heat and blood stasis [2,3] where the anti-cancer effects of Chinese goldthread and turmeric can be explained as damp-heat removing [2, 13] and blood stasis improving [13], respectively. The use of Chinese goldthread and turmeric complement our previous studies involving a polyherbal mixture containing these two herbal extracts [7-9].

While Chinese goldthread (Coptis chinensis) has been tested in a number of cancers [14-17], very little is known about its impact on PCa. Instead, berberine, the major bioactive phytochemical in Chinese goldthread (estimated to be $\sim 6 \%[18,19]$ ) has been preferentially 
studied and has been found to inhibit cell growth at concentrations of $30 \mu \mathrm{M}$ to $100 \mu \mathrm{M}$ in androgen-dependent and androgen-independent PCa cells [17, 20, 21].

Table 2. Effect of oral dosing of curcumin from a single dose (g) to 24 weeks treatment (g/d) on maximum serum/plasma concentrations $(\mathrm{nM})$ of curcumin and its metabolic derivatives

\begin{tabular}{llll} 
Reference & Dose & $\begin{array}{l}\text { Curcumin } \\
\text { (underivatized })\end{array}$ & $\begin{array}{l}\text { Tota } \\
(\text { curc } \\
(\mathrm{nM})\end{array}$ \\
\hline LC or GC Mass Spectral Analysis \\
\hline$[54]$ & 0.45 & nd & \\
& 1.8 & nd & \\
& 3.6 & nd-11 & 35.8 \\
{$[55]$} & 4 & 21 & 149 \\
{$[56]$} & 0.03 & 4.9 &
\end{tabular}

\section{HPLC-UV Detection}

[57]

$\begin{array}{ll}2 & \text { nd } \\ 4 & \text { nd } \\ 6 & \text { nd } \\ 8 & \text { nd } \\ 10 & 137\end{array}$

[58]

$12 \quad 157$

4510

$6 \quad 630$

$8 \quad 1770$

0.45

$1.8<3$

0.18 nd

nd

nd: not detectable.

A minor constituent in this herb is coptisine (ratio of berberine to coptisine is approximately 5:1) [18]; however, this compound and the potential synergy between these compounds has yet to be tested. Turmeric (Curcuma longa) is a plant commonly found in Asia from the ginger 
family. Like Chinese goldthread, extracts of turmeric are not typically used in studies; instead curcumin, one of its primary ingredients known for its anticancer properties, is the primary target of investigation [22, 23]. Curcumin is the major curcuminoid in turmeric at a level of $~ 5-6 \%$ [24, 25]. The molecular targets of curcumin are extensive (as reviewed elsewhere [22, 26]). For example, curcumin has been shown to modify those targets involved in inflammation, apoptosis, angiogenesis, metastasis and the expression of transcription factors, various receptors, growth factors and a variety of protein kinases. However, curcumin inhibits androgen-dependent and androgen-independent PCa cell growth at concentrations of $40 \mu \mathrm{M}$ to $100 \mu \mathrm{M}$ [27]. While the diversity of compounds in turmeric is extensive [28, 29], a less commonly studied one is arturmerone from the sesquiterpenes (ratio of curcumin to ar-turmerone in turmeric is approximately $4: 1)$ [30,31], with reported $\mathrm{IC}_{50}$ values in a variety of cancer cell lines of >243 $\mu \mathrm{M}$ [32-36]; however, ar-turmerone has not been studied in PCa. Similarly, the potential synergy between these compounds has yet to be tested. The objective of this study was to build upon the concept that the combination of bioactives in botanicals is far more effective than an individual bioactive in isolation. While this seems intuitive, a systematic approach yielding solid experimental evidence has yet to be fully explored. To address this issue, we determined if synergy could explain the enhanced effect of $(a)$ the combination of herbs over isolated bioactives derived from those herbs, $(b)$ the combination of bioactives over isolated bioactives derived from the same herb (companion compounds), (c) the combination of herbs over individual herbs, $(d)$ the combination of bioactives from different herbs over the isolated bioactives, and $(e)$ whether these synergistic effects on proliferation can apply at the molecular level. NF- $\mathrm{kB}$ transcriptional activity was chosen as the molecular target because of its link in castrate-resistant PCa [37, 38] and because it has been previously identified as a target of bioactive phytonutrients and natural products $[39,40]$.

\section{MATERIALS AND METHODS:}

Experimental design: The experimental design for testing synergistic interactions is presented in Figure 1. The comparisons made in this study included the combinations of herbs (interinteractions), comparison of the herb to its major bioactive (i.e., Chinese goldthread versus berberine and turmeric versus curcumin), combinations of bioactives from the same herb (intrainteraction) and combinations of bioactives from different herbs (inter-interactions).

Chemicals: The herbal extracts of Chinese goldthread (Coptis chinensis) and turmeric (Curcuma longa) were provided by New Chapter (Brattleboro, VT). Fourier transform infrared spectroscopy was used to independently identify the raw materials and they were further verified by independent laboratories using a variety of analytical approaches (i.e., high performance and thin layer chromatographies and mass spectrometry) (as described previously) [63]. Quality control was determined by ranges of select bioactives, such as curcuminoids in turmeric and berberine in Chinese goldthread [63]. Berberine (98\% purity) was purchased from MP Biomedicals (Solon, OH), curcumin (98\% purity) from Fischer Scientific (Pittsburgh, PA), coptisine (98\% purity) from Quality Phytochemicals (Edison, NJ), and ar-turmerone (90\% purity) from Sigma-Aldrich (St. Louis, MO). All substances were dissolved in dimethyl sulfoxide (DMSO) (Sigma-Aldrich, St. Louis, MO) to varied stock concentrations. RPMI 1640 
cell culture media (Invitrogen, Grand Island, NY), supplemented with $0.5 \%$ fetal bovine serum (FBS, Invitrogen, Grand Island, NY) was used to dilute each stock solution to the required final concentrations.

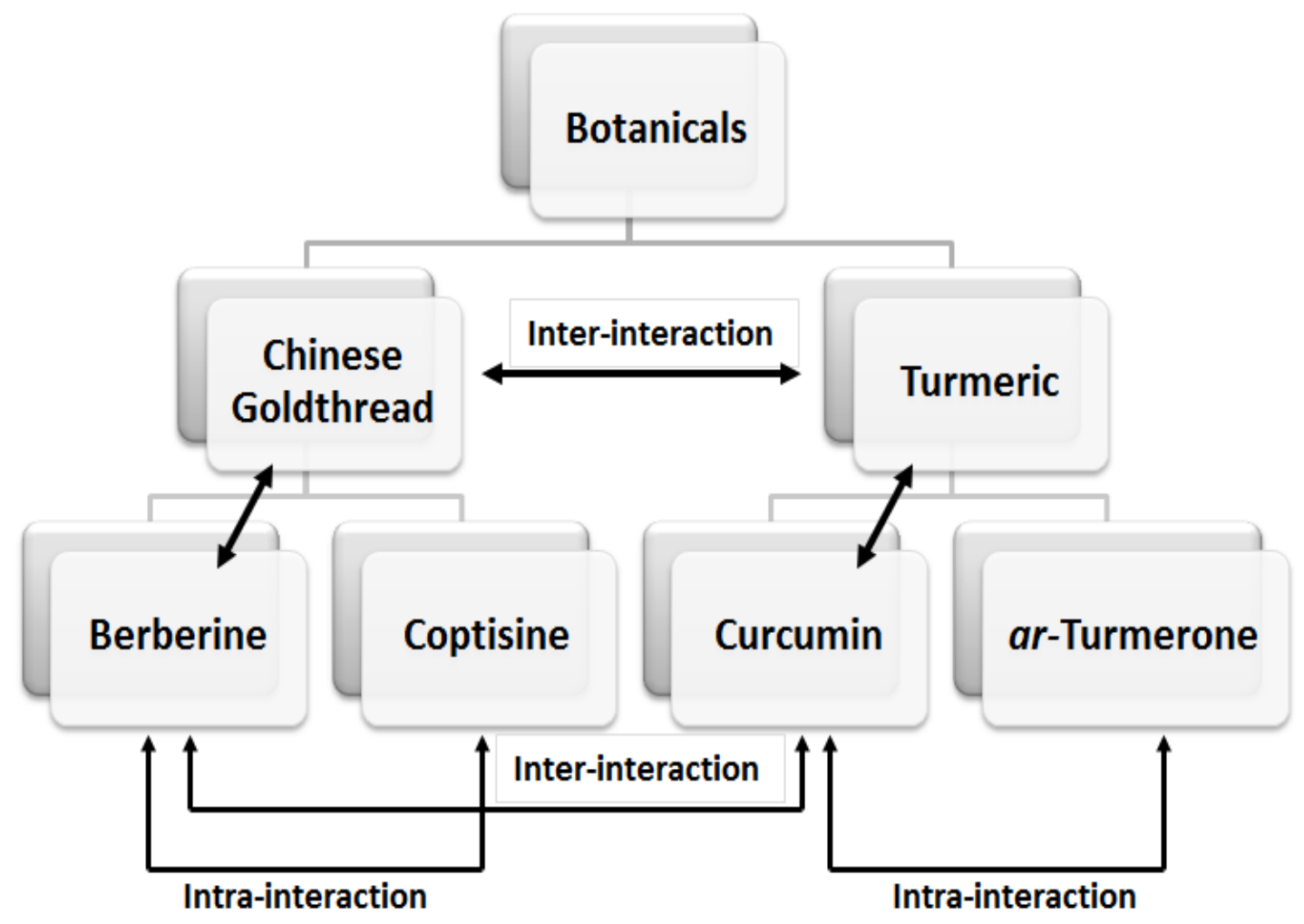

Figure 1. Experimental design. Comparisons were made between herbs and their major bioactives, among combinations of herbs (inter-interaction of herbs) and combinations of bioactives from the same herb (intra-interaction of isolated bioactives) or different herbs (interinteractions of isolated bioactives).

Cell Culture: For the experimental treatments, CWR22Rv1 cells (American Type Culture Collection, Rockville, MD), a human-derived castrate-resistant PCa line, were grown in RPMI 1640 media supplemented with $10 \%$ FBS under an atmosphere of $5 \% \mathrm{CO}_{2}$ at $37^{\circ} \mathrm{C}$. Prior to the experiments, the level of FBS was reduced to 0.5\%. HEK293 cells (ATCC, Rockville, MD), a human embryonic kidney cell line, were grown in DMEM media supplemented with $10 \%$ FBS under an atmosphere of $5 \% \mathrm{CO}_{2}$ at $37^{\circ} \mathrm{C}$.

Cell Proliferation: Cell growth and proliferation inhibition studies were performed using standard 96 well plates and analyzed with the MTT [3-(4, 5-dimethylthiazol-2-yl)-2, 5diphenyltetrazolium bromide] (Chalbiochem, Darmstadt, Germany) assay following the manufacturer's instructions. CW22Rv1 cells were plated at a density of $2 \times 10^{4}$ cells per well. After 24 hours, the FBS concentration in the cell culture media was reduced to $0.5 \%$ FBS and the cells were incubated overnight prior to the addition of the herbal extracts or phytochemicals. 
HEK293 cells were plated at a density of $1 \times 10^{4}$ cells per well. After 24 hours, the cells were incubated with herbal extracts or phytochemicals. After $48 \mathrm{hr}$ incubation, cell viability and proliferation were measured via the MTT assay. Briefly, medium was replaced by $100 \mu \mathrm{l}$ of 0.5 $\mathrm{mg} / \mathrm{ml} \mathrm{MTT}$ and cells were incubated for $4 \mathrm{hr}$ at $37^{\circ} \mathrm{C}$. Intracellular formazan crystals were solubilized with $100 \mu \mathrm{l}$ isopropanol/0.04 N HCl. Absorbance was read at $540 \mathrm{~nm}$ on a SpectraCount microplate photometer (Perkin Elmer Inc, Waltham, MA).

Transfection and luciferase assay: The multimerized NF- $\mathrm{B}$ promoter luciferase vector has been described elsewhere [11]. Transient transfection of luciferase reporter constructs into HEK293 cells was achieved using Lipofectamine ${ }^{\circledR} 2000$ (Life technologies, Grand Island, NY) following manufacturer's instructions. Briefly, HEK293 cells were plated at a density of $1.5 \times 10^{4}$ cells per well in 96 well plates. After 24 hours, $4 \mathrm{ng} /$ well plasmid was transfected with 0.32 $\mu \mathrm{l} /$ well Lipofectamine ${ }^{\circledR} 2000$. After incubating overnight, transfection medium was removed and cells were incubated with herbal extracts or phytochemicals in 0.5\% FBS supplemented DMEM medium for $1 \mathrm{hr}$. After incubation, HEK293 cells with luciferase reporter were stimulated by 5 ng/ml TNF- $\alpha$ for $4 \mathrm{hr}$. Whole cell lysate was achieved by $20 \mu \mathrm{l}$ passive lysis buffer (Promega, Madison, WI) and $10 \mu \mathrm{l}$ was used for luciferase activity measurement by using the Luciferase Assay Reagent (Promega, Madison, WI). Luciferase activity was detected using the GloMax plate reading luminometer and normalized to total cellular protein concentration per well using the BCA assay (Thermo Scientific, Rockford, IL) following manufacturer's instruction.

\section{Assessment of Synergistic, Additive or Antagonistic Effects of Combinations of Herbal} Extracts and/or Phytochemicals: To calculate the effects of compounds or herbs in combination, $\mathrm{IC}_{50}$ values were determined for each ingredient. For the experiments with the combination of herbal extracts, turmeric and Chinese goldthread were combined at a concentration equivalent to their $\mathrm{IC}_{50}$ values followed by serial dilutions to generate a dose response. For the experiments that combined individual bioactive phytochemicals from different herbal extracts (berberine and curcumin), they were combined at concentrations equivalent to their $\mathrm{IC}_{50}$ values, followed by serial dilutions to generate a dose response. For the experiments that combined individual bioactive phytochemicals from the same herbal extract (i.e., berberine and coptisine, curcumin and ar-turmerone), they were combined at concentrations equivalent to their $\mathrm{IC}_{50}$ values or based on their relative ratios in their respective herbal extracts followed by serial dilutions to generate dose responses.

Assessment of synergistic, additive or antagonistic effects of combinations was determined using the Chou-Talalay method [64]. This method is derived from mass-action law principles as described in detail elsewhere [65]. The combination index (CI) and dose-reduction index (DRI) were used to differentiate synergy, antagonism and additive effects for combinations of components. CI and DRI were generated for all treatments with CompuSyn ${ }^{\circledR} 1.0$ (Combo Syn, Paramus, NJ) according to the manufacturer's instructions. CompuSyn ${ }^{\circledR} 1.0$ software uses an algorithm based on the Chou-Talalay method to simulate the interaction of 2 or more compounds. Briefly, concentrations and corresponding effect levels for all data points were input to generate a complete report of analytical results. CI is a parameter that indicates whether the interaction of two compounds is synergistic, additive, or antagonistic [additive $(\mathrm{CI}=1)$; 
synergistic $(\mathrm{CI}<1)$; antagonistic $(\mathrm{CI}>1)]$. DRI is a parameter that indicates the degree to which the concentration of a compound can be reduced when used in combination with another compound to maintain an equivalent effect. The use of CI and DRI provide numerical assessments of not only whether there is synergy, but the extent of that synergy and synergy at particular doses [64].

Statistical Analysis: The results were presented as mean \pm SEM and were analyzed by twotailed student's T-test. Differences were considered significant at $\mathrm{p}<0.05$.

\section{RESULTS:}

\section{Cell proliferation:}

Dose response curves were generated for all bioactives tested in each cell type. All the bioactives and their extracts of origin reduced cell proliferation in a dose dependent manner (Fig. 2). IC $_{50}$ values of bioactives were used, in part, to determine the synergistic effect between different bioactives.
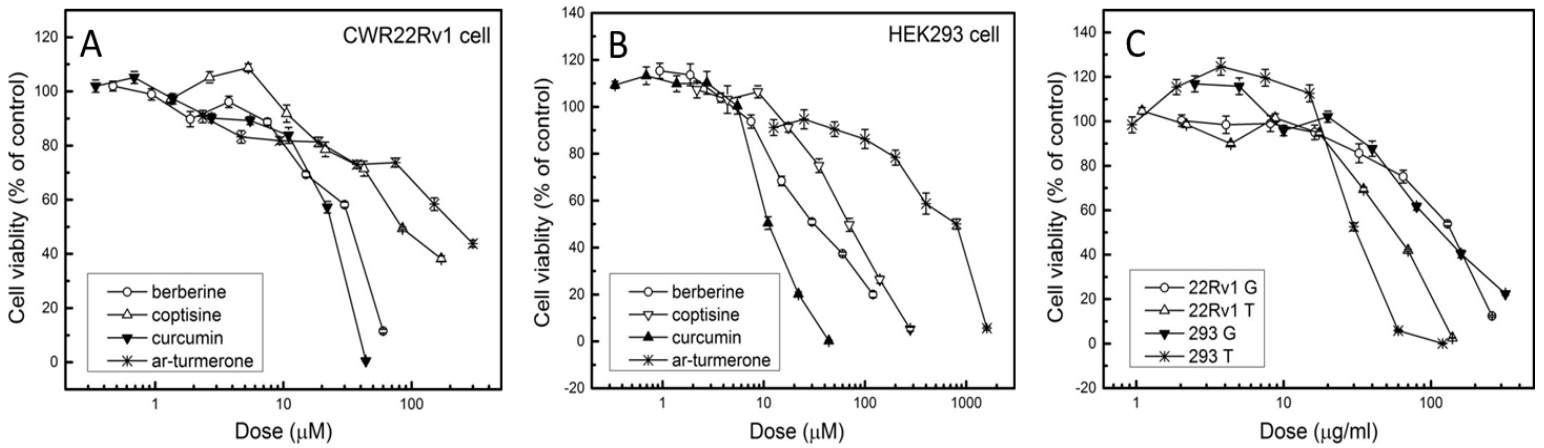

Figure 2. The effects of berberine, coptisine, curcumin, ar-turmerone, Chinese goldthread and turmeric on cell proliferation. Dose-response curves for cell proliferation were generated with berberine, coptisine, curcumin, ar-turmerone using (A) CWR22Rv1 cells and (B) HEK293 cells. (C) Dose-response curves for cell proliferation were also generated with the herbal extracts of Chinese goldthread and turmeric for both cell lines. $\mathrm{IC}_{50}$ values of bioactives and herb extracts were generated from these curves.

\section{Comparisons of Chinese goldthread with berberine, and turmeric with curcumin on cell} proliferation: Dose-response curves were generated for Chinese goldthread, berberine, turmeric and curcumin and their effectiveness inhibiting cell proliferation were compared based on the relative amounts of the phytonutrients in the herbal extract (i.e., the amount of berberine in Chinese goldthread and the amount of curcumin in turmeric). Proliferation of CWR22Rv1cells and HEK293 cells was reduced in dose-dependent manners with Chinese goldthread and berberine (Fig. 2). Following normalization based on the relative amount of berberine in Chinese goldthread, there was a shift to the left in the $\mathrm{IC}_{50}$ value, from $30 \mu \mathrm{M}$ to $19 \mu \mathrm{M}$ in CWR22Rv1 cells (Fig. 3A) and from $30 \mu \mathrm{M}$ to $11 \mu \mathrm{M}$ in HEK293 cells (Fig. 3C).

Cell proliferation was also reduced in dose-dependent manners with turmeric and curcumin (Fig. 2). Following normalization based on the relative amount of curcumin in turmeric, there was a shift to the left of the $\mathrm{IC}_{50}$ value from $22 \mu \mathrm{M}$ to $9.5 \mu \mathrm{M}$ in CWR22Rv1 cells (Fig. 3B) and from $11 \mu \mathrm{M}$ to $4 \mu \mathrm{M}$ in HEK293 cells (Fig. 3D). These results collectively infer that other 
compounds within the original herbal extracts (companion compounds) may be acting in concert (i.e., synergism) with each of the bioactive phytonutrients. To explore this possibility, we investigated the effects of combining companion phytonutrients from Chinese goldthread (i.e., berberine with coptisine) and turmeric (i.e., curcumin with ar-turmerone).

Intra-herbal comparisons of companion phytonutrients (berberine with coptisine, curcumin with ar-turmerone) on cell proliferation: Berberine and coptisine are two bioactive phytonutrients found in Chinese goldthread (companion phytonutrients) and their synergy could help explain, in part, the enhanced effectiveness of Chinese goldthread when compared with berberine in isolation. Berberine and coptisine reduced the proliferation of CW22Rv1 cells in dose-dependent manners with $\mathrm{IC}_{50}$ values of $30 \mu \mathrm{M}$ and $85 \mu \mathrm{M}$, respectively (Fig. 2). In a similar manner, the proliferation of HEK293 cells was reduced by berberine and coptisine with IC $_{50}$ values of $30 \mu \mathrm{M}$ and $70 \mu \mathrm{M}$, respectively (Fig. 2). To determine the effects on proliferation with the combination, cells were treated with berberine plus coptisine with serial dilutions starting with concentrations equivalent to their $\mathrm{IC}_{50}$ values $(30 \mu \mathrm{M}: 85 \mu \mathrm{M}$ for CWR22Rv1, 30
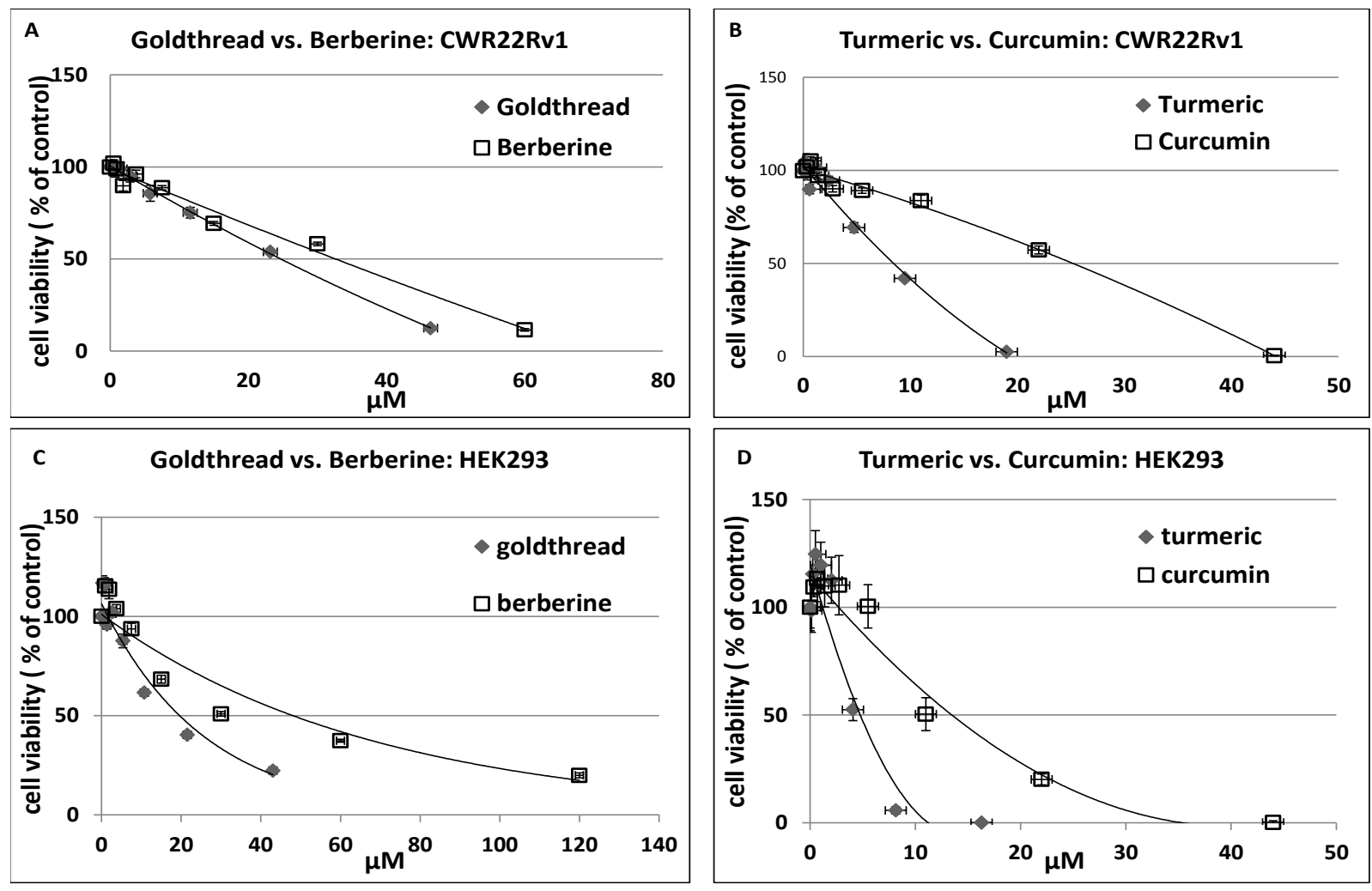

Figure 3. The comparison of berberine and curcumin on cell proliferation compared to their herbal extracts of origin, Chinese goldthread and turmeric, respectively, in CWR22Rv1 cells and HEK293 cells. Following normalization based on the relative amount of berberine in Chinese goldthread and the relative amount of curcumin in turmeric, dose-response curves were compared between Chinese goldthread and berberine in (A) CWR22Rv1 cells and (C) HEK293 cells, and between turmeric and curcumin in (B) CWR22Rv1 cells and (D) HEK293 cells. Compared to individual compounds, herbal extracts had a more pronounced effect on reducing cell proliferation compared to their isolated bioactives (shifts in $\mathrm{IC}_{50}$ values to the left). 
$\mu \mathrm{M}: 70 \mu \mathrm{M}$ for HEK293) and reducing these to nanomolar concentrations while maintaining the same ratio. The combination of berberine plus coptisine reduced cell proliferation in a dosedependent manner and the minimum effective doses were determined for both single phytochemicals and their combinations (Tables 3 and 4). CI and DRI values were generated for minimum effective doses by CompuSyn ${ }^{\circledR}$ 1.0, respectively. The combination of berberine plus coptisine reduced the minimum effective doses from $\mu \mathrm{M}$ level to $\mathrm{nM}$ level in CWR22Rv1 cells (7.5 $\mu \mathrm{M}$ for berberine, $21 \mu \mathrm{M}$ for coptisine, and $0.24 \mu \mathrm{M}+0.66 \mu \mathrm{M}$ for their combination) and was highly synergistic in inhibiting cell growth at this level (CI equal to 0.05), with the DRIs being 52 and 37 when combined at the lowest concentrations $(0.24 \mu \mathrm{M}+0.66 \mu \mathrm{M})$. This means the addition of berberine to coptisine or coptisine to berberine reduced the effective doses 52 and 37 fold, respectively, compared with each alone. In a similar manner, the combination of berberine plus coptisine also reduced the minimum effective doses significantly in HEK293 cells (15 $\mu \mathrm{M}$ for berberine, $17.5 \mu \mathrm{M}$ for coptisine, and 3.75 $\mu \mathrm{M}+8.75 \mu \mathrm{M}$ for combination) and was highly synergistic in inhibiting cell growth at this level (CI equal to 0.42 with the DRIs being 3.2 and 32).

Curcumin and ar-turmerone (two bioactive phytonutrients found in turmeric) reduced the proliferation of CW22Rv1 cells in dose-dependent manners with $\mathrm{IC}_{50}$ values of $22 \mu \mathrm{M}$ and 150 $\mu \mathrm{M}$, respectively (Table 3). In a similar manner, the proliferation of HEK293 cells was reduced by curcumin and ar-turmerone with $\mathrm{IC}_{50}$ values of $11 \mu \mathrm{M}$ and $200 \mu \mathrm{M}$, respectively (Table 4). To determine the effects on proliferation with the combination, cells were treated with curcumin plus ar-turmerone with serial dilutions starting with concentrations equivalent to their $\mathrm{IC}_{50}$ values $(22 \mu \mathrm{M}: 150 \mu \mathrm{M}$ for CWR22Rv1, $11 \mu \mathrm{M}: 200 \mu \mathrm{M}$ for HEK293) and reducing these to nanomolar concentrations while maintaining the same ratio (Tables 3 and 4). The dose-response curves with the combination of curcumin plus ar-turmerone reduced cell proliferation in a dosedependent manner. The combination of curcumin plus ar-turmerone reduced the minimum effective doses in CWR22Rv1 cells (5.5 $\mu \mathrm{M}$ for curcumin, $9.4 \mu \mathrm{M}$ for ar-turmerone, and 0.17 $\mu \mathrm{M}+1.2 \mu \mathrm{M}$ for their combination) and was highly synergistic in inhibiting cell growth at this level (CI equal to 0.09 with the DRIs being 37 and 16). In a similar manner, the combination of curcumin plus ar-turmerone also reduced the minimum effective doses significantly in HEK293 cells $(11 \mu \mathrm{M}$ for curcumin, $200 \mu \mathrm{M}$ for ar-turmerone, $0.69 \mu \mathrm{M}+25 \mu \mathrm{M}$ for their combination) and was highly synergistic in inhibiting cell growth at this level (CI equal to 0.45 with the DRIs being 14 and 2.6).

While it is standard practice to use the ratio of the $\mathrm{IC}_{50}$ values to evaluate synergy, the ratio of these bioactive phytonutrients from their respective herbal extracts are different. For example, the ratio of berberine to coptisine in Chinese goldthread is $\sim 5: 1$, and curcumin to ar-turmerone is 4:1. As such, synergy was also assessed at more "natural" ratios (Tables 3 and 4). For CWR22Rv1 cells, the combination of berberine and coptisine was highly synergistic in inhibiting cell growth at minimum effective concentrations $(0.469 \mu \mathrm{M}+0.094 \mu \mathrm{M})$ where the CI was 0.16 , respectively. The DRI values at these concentrations were 6.8 and 14.6 for berberine and coptisine, respectively. Similarly, using HEK293 cells, the combination of berberine and coptisine in a 5:1 ratio was highly synergistic in inhibiting cell growth in minimum effective concentrations $(1.88 \mu \mathrm{M}+0.38 \mu \mathrm{M})$ where the CI was 0.10 , respectively. The DRI values at these concentrations were 11 and 109 for berberine and coptisine, respectively. 
Using CWR22Rv1 cells, the combination of curcumin plus ar-turmerone were also highly synergistic in inhibiting cell growth at concentrations as low as $0.344 \mu \mathrm{M}+0.086 \mu \mathrm{M}$, respectively (Table 3 ), where the CI was 0.06 . The DRI values at these concentrations were 17.6 and 187 for curcumin and ar-turmerone, respectively. Using HEK293 cells, the combination of curcumin and ar-turmerone was synergistic in inhibiting cell growth at minimum effective concentrations of $11 \mu \mathrm{M}+2.75 \mu \mathrm{M}$, respectively, where the CI was 0.64 (Table 4). The DRI values at these concentrations were 2.4 and 3.8 for curcumin and ar-turmerone, respectively.

Inter-herbal comparison of the extracts of Chinese goldthread with turmeric on cell proliferation: The extracts of Chinese goldthread and turmeric reduced the proliferation of CWR22Rv1 and HEK293 cells in dose-dependent manners ( IC $_{50}$ values for CWR22Rv1 cells were $130 \mu \mathrm{g} / \mathrm{ml}$ and $65 \mu \mathrm{g} / \mathrm{ml}$, for HEK293 cells were $80 \mu \mathrm{g} / \mathrm{ml}$ and $30 \mu \mathrm{g} / \mathrm{ml}$, respectively) (Fig. 2). To determine the effects on proliferation with the combination, cells were treated with Chinese goldthread plus turmeric with serial dilutions starting with combined concentrations equivalent to their IC I0 $_{50}$ values $(130 \mu \mathrm{g} / \mathrm{ml}: 65 \mu \mathrm{g} / \mathrm{ml}$ for CWR22Rv1 cells and $80 \mu \mathrm{g} / \mathrm{ml}: 30 \mu \mathrm{g} / \mathrm{ml}$ for HEK293 cells) and going as low as $\leq 1 \mu \mathrm{g} / \mathrm{ml}$ (maintaining the same ratio). The combination of Chinese goldthread plus turmeric qualitatively reduced cell proliferation in a dose-dependent manner for both cell lines (Tables 3 and 4). CI and DRI values were generated at minimum effective concentrations. For CWR22Rv1 cells, the minimum effective concentration was more than 100 times lower than their respective $\mathrm{IC}_{50}$ values $(1.103 \mu \mathrm{g} / \mathrm{ml}+0.508 \mu \mathrm{g} / \mathrm{ml}$, respectively). The combination of Chinese goldthread and turmeric were highly synergistic in inhibiting cell growth at these doses, where the CI was 0.04 , respectively. The DRI values at the minimum effective concentrations were 51.6 and 52.1 for Chinese goldthread and turmeric, respectively. Using HEK293 cells, the minimum effective concentrations were significantly reduced to 10 $\mu \mathrm{g} / \mathrm{ml}+3.75 \mu \mathrm{g} / \mathrm{ml}$. The combination was highly synergistic at these doses, where the CI was 0.29 . The DRI values at the minimum effective concentrations were 6.8 and 6.8 , respectively.

Inter-herbal comparison of phytonutrients (berberine with curcumin): To explain, in part, the synergism between Chinese goldthread and turmeric, isolated bioactive compounds from each herb (i.e., berberine and curcumin) were evaluated for synergy. To determine the effects on proliferation with the combination, cells were treated with berberine plus curcumin with serial dilutions starting with concentrations equivalent to their $\mathrm{IC}_{50}$ values $(30 \mu \mathrm{M}: 22 \mu \mathrm{M}$ for CWR22Rv1 cells and $30 \mu \mathrm{M}: 11 \mu \mathrm{M}$ for HEK293 cells) and reducing these to nanomolar concentrations while maintaining the same ratio. The combination of berberine plus curcumin reduced cell proliferation in a dose-dependent manner for both cell lines (Tables 3 and 4). CI and DRI values were generated for minimum effective concentrations. For CWR22Rv1 cells, the combination of berberine and curcumin was highly synergistic in inhibiting cell growth at these levels (CI equal to 0.08 , respectively), with the DRIs being 23.5 and 23.7 when combined at the minimum effective concentrations $(0.235 \mu \mathrm{M}+0.172 \mu \mathrm{M})$ (Table 3). Similar results were observed with HEK293 cells (Table 4). The combination of berberine and curcumin was highly synergistic in inhibiting cell growth at these levels (CI equal to 0.32), with the DRIs being 5.3 and 7.5 when combined at the minimum effective concentrations $(3.75 \mu \mathrm{M}+1.38 \mu \mathrm{M})$. 
Table 3: Dose-effect relationships of berberine and coptisine (from Chinese goldthread), curcumin and ar-turmerone (from turmeric), Chinese goldthread and turmeric and their combinations using their $\mathrm{IC}_{50}$ values or using ratios corresponding to relative amounts in their native extracts on proliferation of CWR22Rv1 cells.

\begin{tabular}{|c|c|c|c|c|}
\hline $\begin{array}{l}\text { Isolated compounds } \\
\text { and combinations }\end{array}$ & $\begin{array}{l}\text { Minimum } \\
\text { Effective Dose } \\
(\mu \mathrm{M})^{\mathrm{a}}\end{array}$ & $\begin{array}{l}\mathrm{IC}_{50} \\
(\mu \mathrm{M})\end{array}$ & $\begin{array}{l}\text { Combination } \\
\text { Index (CI) }\end{array}$ & $\begin{array}{l}\text { Dose Reduction Index } \\
\text { (DRI) }\end{array}$ \\
\hline Berberine & 7.5 & 30 & & \\
\hline Coptisine & 21 & 85 & & \\
\hline $\begin{array}{l}\text { Ber + Cop } \\
(\text { ratio }=1: 2.8)^{b}\end{array}$ & $0.24+0.66$ & & 0.05 & $\begin{array}{l}\text { Berberine: } 52 \\
\text { Coptisine: } 37\end{array}$ \\
\hline $\begin{array}{l}\text { Ber + Cop } \\
(\text { ratio }=5: 1)^{\mathrm{c}}\end{array}$ & $0.47+0.09$ & & 0.16 & $\begin{array}{l}\text { Berberine: } 7 \\
\text { Coptisine: } 15 \\
\end{array}$ \\
\hline Curcumin & 5.5 & 22 & & \\
\hline ar-turmerone & 9.4 & 150 & & \\
\hline $\begin{array}{l}\text { Cur + ar-tur } \\
(\text { ratio }=1: 6.8)^{b}\end{array}$ & $0.17+1.2$ & & 0.09 & $\begin{array}{l}\text { Curcumin: } 37 \\
\text { ar-turmerone: } 16\end{array}$ \\
\hline $\begin{array}{l}\text { Cur + ar-tur } \\
(\text { ratio }=4: 1)^{\mathrm{d}}\end{array}$ & $0.34+0.09$ & & 0.06 & $\begin{array}{l}\text { Curcumin: } 18 \\
\text { ar-turmerone: } 87\end{array}$ \\
\hline Berberine & 7.5 & 30 & & \\
\hline Curcumin & 5.5 & 22 & & \\
\hline $\begin{array}{l}\text { Ber + Cur } \\
(\text { ratio }=1.4: 1)^{\mathrm{b}}\end{array}$ & $0.24+0.17$ & & 0.16 & $\begin{array}{l}\text { Berberine: } 24 \\
\text { Curcumin: } 24\end{array}$ \\
\hline $\begin{array}{l}\text { Isolated herbal } \\
\text { extracts and } \\
\text { combinations }\end{array}$ & $\begin{array}{l}\text { Minimum } \\
\text { Effective Dose } \\
(\mu \mathrm{g} / \mathrm{ml})^{\mathrm{a}}\end{array}$ & $\begin{array}{l}\mathrm{IC}_{50} \\
(\mu \mathrm{g} / \mathrm{ml})\end{array}$ & $\begin{array}{l}\text { Combination } \\
\text { Index (CI) }\end{array}$ & $\begin{array}{l}\text { Dose Reduction Index } \\
\text { (DRI) }\end{array}$ \\
\hline Chinese Goldthread & 65 & $130 \mu \mathrm{g} / \mathrm{ml}$ & & \\
\hline Turmeric & 35 & $65 \mu \mathrm{g} / \mathrm{ml}$ & & \\
\hline $\begin{array}{l}\text { Chinese GT + Tur } \\
(\text { ratio }=2: 1)^{\mathrm{b}}\end{array}$ & $1.10+0.51$ & & 0.14 & $\begin{array}{l}\text { Chinese GT: } 52 \\
\text { Turmeric: } \quad 52\end{array}$ \\
\hline
\end{tabular}

Table 4: Dose-effect relationships of berberine and coptisine (from Chinese goldthread), curcumin and ar-turmerone (from turmeric), Chinese goldthread and turmeric and their combinations using their $\mathrm{IC}_{50}$ values or using ratios corresponding to relative amounts in their native extracts on proliferation of HEK293 cells.

\begin{tabular}{|c|c|c|c|c|}
\hline $\begin{array}{l}\text { Isolated compounds and } \\
\text { combinations }\end{array}$ & $\begin{array}{l}\text { Minimum } \\
\text { Effective Dose } \\
(\mu \mathrm{M})^{\mathrm{a}}\end{array}$ & $\begin{array}{l}\mathrm{IC}_{50} \\
(\mu \mathrm{M})\end{array}$ & $\begin{array}{l}\text { Combination } \\
\text { Index (CI) }\end{array}$ & $\begin{array}{l}\text { Dose Reduction Index } \\
\text { (DRI) }\end{array}$ \\
\hline Berberine & 15 & 30 & & \\
\hline Coptisine & 18 & 70 & & \\
\hline Ber + Cop & $3.75+8.75$ & & 0.42 & Berberine: 5.2 \\
\hline$(\text { ratio }=1: 2.3)^{b}$ & & & & Coptisine: 4.5 \\
\hline Ber + Cop & $1.88+0.38$ & & 0.10 & Berberine: 11 \\
\hline$(\text { ratio }=5: 1)^{\mathrm{c}}$ & & & & Coptisine: 109 \\
\hline Curcumin & 11 & 11 & & \\
\hline ar-turmerone & 200 & 400 & & \\
\hline Cur + ar-tur & $0.69+25$ & & 0.45 & Curcumin: 15 \\
\hline$(\text { ratio }=1: 36)^{b}$ & & & & ar-turmerone: \\
\hline \multirow{4}{*}{$\begin{array}{l}\text { Cur }+ \text { ar-tur } \\
(\text { ratio }=4: 1)^{\mathrm{d}}\end{array}$} & & & \multicolumn{2}{|r|}{2.6} \\
\hline & $11+2.75$ & & 0.64 & Curcumin: 2.8 \\
\hline & & & & ar-turmerone: \\
\hline & & & \multicolumn{2}{|r|}{1.4} \\
\hline Berberine & 15 & 30 & & \\
\hline Curcumin & 11 & 11 & & \\
\hline
\end{tabular}




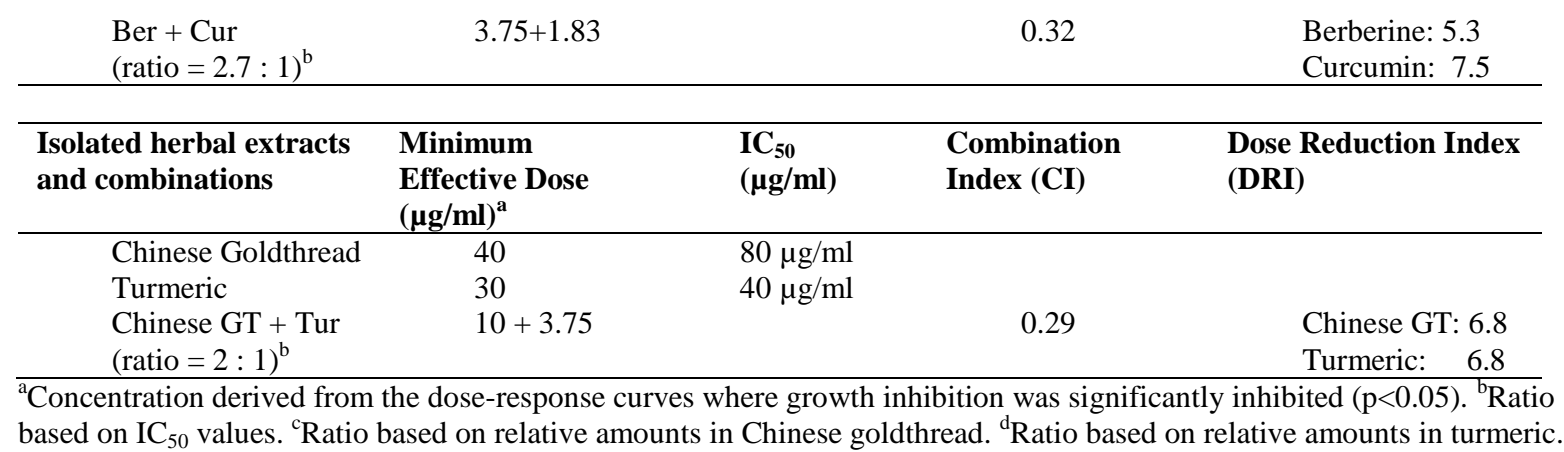

TNFa-stimulated NF-кB transcriptional activity: Dose response curves were generated for all bioactives and extracts tested in HEK293 cells. All the bioactives and their extracts of origin, except berberine and Chinese goldthread, reduced NF- $\mathrm{KB}$ transcriptional activity in a dose dependent manner (Fig. 4). $\mathrm{IC}_{50}$ values of bioactives were used, in part, to determine the synergistic effect between different bioactives.
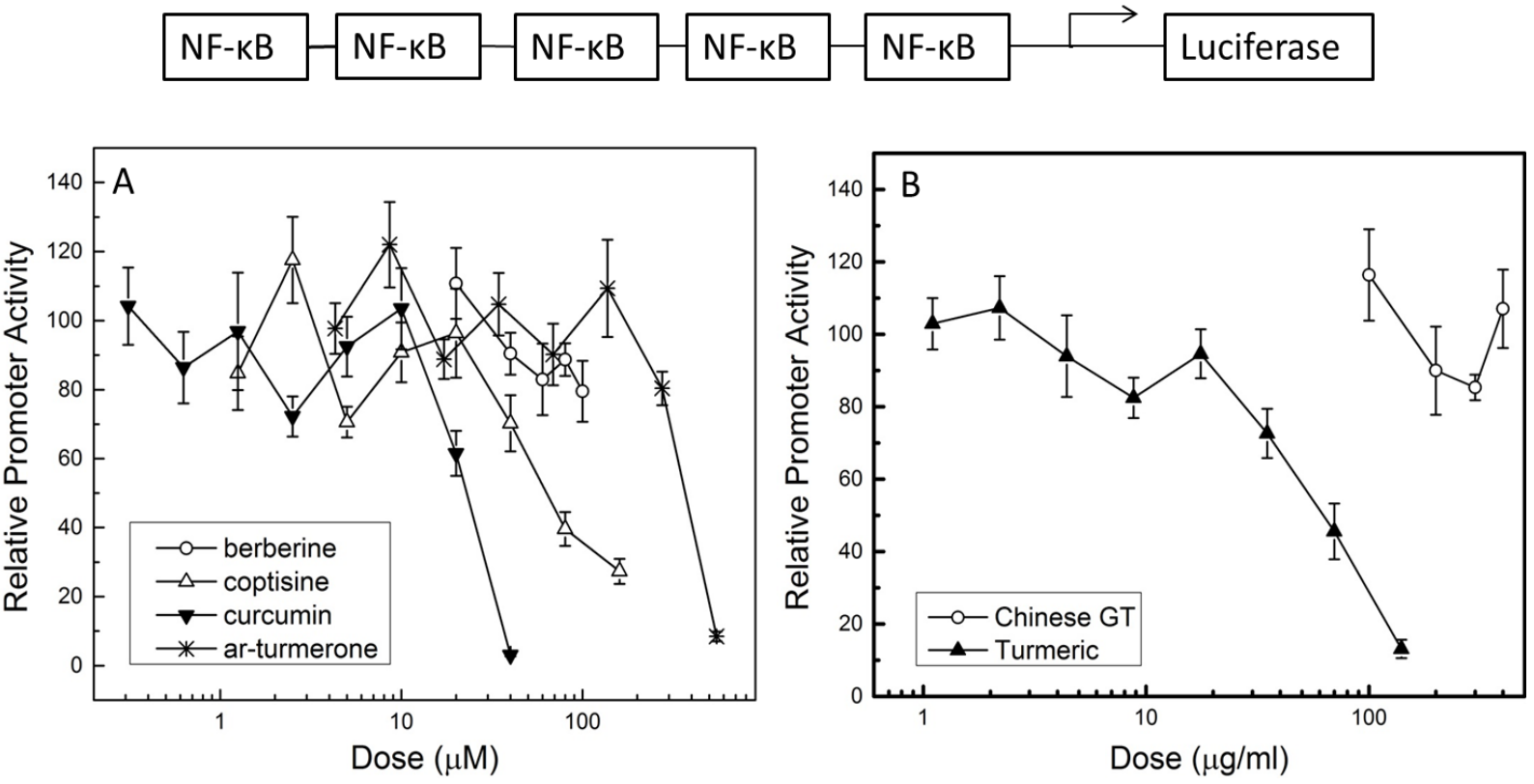

Figure 4. The effects of berberine, coptisine, curcumin, ar-turmerone, Chinese goldthread and turmeric on inhibition of TNF $\alpha$-stimulated NF-kB transcriptional activity in HEK293 cells. Dose-response curves were generated with (A) berberine, coptisine, curcumin, ar-turmerone) and (B) Chinese goldthread and turmeric. $\mathrm{IC}_{50}$ values of the bioactives and turmeric were generated from these curves.

\section{Comparisons of turmeric with curcumin on TNFa-stimulated NF- $\mathrm{BB}$ transcriptional} activity: Dose-response curves were generated for turmeric and curcumin and their effectiveness inhibiting NF- $\mathrm{KB}$ transcriptional activity were compared based on the relative amounts of the phytonutrients in the herbal extract (i.e., the amount of curcumin in turmeric). NF- $\mathrm{KB}$ transcriptional activity was reduced in dose-dependent manners with turmeric and curcumin (Fig. 4). Following normalization based on the relative amount of curcumin in turmeric, there was a shift to the left in the $\mathrm{IC}_{50}$ value, from $20 \mu \mathrm{M}$ to $10 \mu \mathrm{M}$ (Fig. 5). These results collectively infer that companion compounds in turmeric may be acting synergistically with curcumin. To explore 
this possibility, we investigated the effects of combining curcumin with one of its companion compounds ar-turmerone.

\section{turmeric $\square$ curcumin}

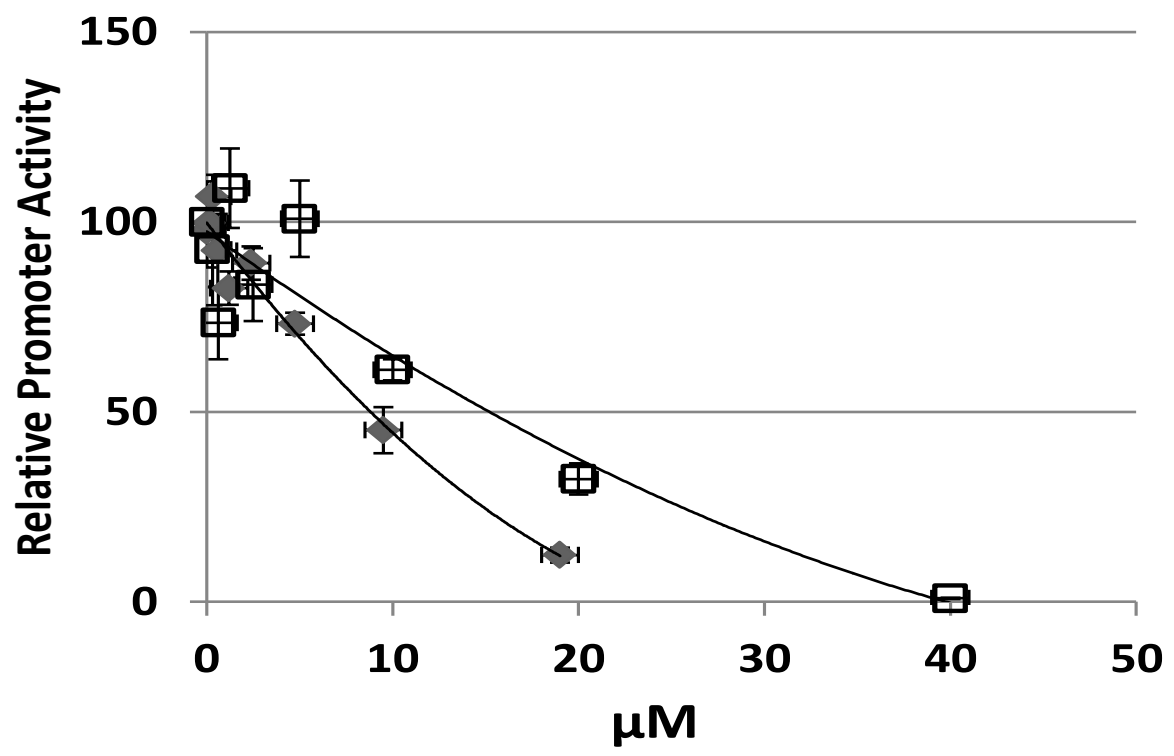

Figure 5. The effects of curcumin and turmeric on inhibition of TNF $\alpha$-stimulated NF- $\kappa \mathrm{B}$ transcriptional activity. HEK 293 cells were treated with serial dilutions of either curcumin or turmeric and inhibition of $\mathrm{TNF} \alpha$-stimulated $N F-\kappa B$ transcriptional activity was determined. Following normalization based on the relative amount of curcumin in turmeric, dose-response curves were compared between curcumin in isolation to turmeric.

Intra-herbal comparisons of companion phytonutrients (curcumin with ar-turmerone) on TNFa-stimulated NF-кB transcriptional activity: Curcumin and ar-turmerone (two bioactive phytonutrients found in turmeric) reduced the NF- $\kappa \mathrm{B}$ transcriptional activity in dose-dependent manners with $\mathrm{IC}_{50}$ values of $20 \mu \mathrm{M}$ and $275 \mu \mathrm{M}$, respectively (Fig. 4). To determine the effects on NF- $\kappa \mathrm{B}$ transcriptional activity with the combination, cells were treated with curcumin plus arturmerone with serial dilutions starting with concentrations equivalent to their $\mathrm{IC}_{50}$ values (20 $\mu \mathrm{M}: 275 \mu \mathrm{M})$ and reducing these to nanomolar concentrations while maintaining the same ratio (Table 5). The dose-response curves with the combination of curcumin plus ar-turmerone reduced $\mathrm{NF}-\kappa \mathrm{B}$ transcriptional activity in a dose-dependent manner. The combination of curcumin plus ar-turmerone reduced the minimum effective concentrations of $20 \mu \mathrm{M}$ for curcumin and $275 \mu \mathrm{M}$ for ar-turmerone to $0.16 \mu \mathrm{M}+2.15 \mu \mathrm{M}$ for their combination, respectively (Table 5). The combination was highly synergistic in inhibiting NF- $\kappa \mathrm{B}$ transcriptional activity (CI equal to 0.01 with the DRIs being 109 and 311). In a similar manner, the combination of curcumin plus ar-turmerone in a ratio based on relative amounts in turmeric (ratio of 4:1; Table 5) also reduced the minimum effective doses significantly from $20 \mu \mathrm{M}$ for curcumin and $275 \mu \mathrm{M}$ for ar-turmerone to $0.63 \mu \mathrm{M}+0.16 \mu \mathrm{M}$ for their combination, respectively. This effect was also highly synergistic in inhibiting NF- $\kappa \mathrm{B}$ transcriptional activity at these concentrations (CI equal to 0.04 with the DRIs being 23 and 3563). 
Inter-herbal comparison of the extracts of Chinese goldthread with turmeric on TNF $\alpha$ stimulated NF-кB transcriptional activity: The extract of Chinese goldthread did not reduce $\mathrm{NF}-\kappa \mathrm{B}$ transcriptional activity using concentrations up to $400 \mu \mathrm{g} / \mathrm{ml}$ (Fig. 4B). In contrast, turmeric reduced the NF- $\kappa \mathrm{B}$ transcriptional activity in a dose-dependent manner $\left(\mathrm{IC}_{50}\right.$ value was $70 \mu \mathrm{g} / \mathrm{ml}$ ) (Fig. 4B). To determine the effects on NF- $\mathrm{B}$ transcriptional activity with the combination, cells were treated with $200 \mu \mathrm{g} / \mathrm{ml}$ Chinese goldthread plus progressive dilutions of turmeric beginning at $70 \mu \mathrm{g} / \mathrm{ml}$. The combination of Chinese goldthread plus turmeric reduced the minimum effective dose of turmeric from $70 \mu \mathrm{g} / \mathrm{ml}$ to $8.75 \mu \mathrm{g} / \mathrm{ml}$ with the combination (Table 5). CI and DRI values were not generated due to the lack of a dose-response curve for Chinese goldthread.

Table 5: Dose-effect relationships of curcumin and ar-turmerone (from turmeric), curcumin (from turmeric) and coptisine (from Chinese goldthread), and Chinese goldthread and turmeric and their combinations using their $\mathrm{IC}_{50}$ values or using ratios corresponding to relative amounts in their native extracts on NF- $\mathrm{BB}$ promoter activity using transfected HEK293 cells.

\begin{tabular}{lllll}
\hline $\begin{array}{l}\text { Isolated compounds and } \\
\text { combinations }\end{array}$ & $\begin{array}{l}\text { Minimum } \\
\text { Effective Dose } \\
(\boldsymbol{\mu M})^{\mathbf{a}}\end{array}$ & $\begin{array}{l}\mathbf{I C}_{\mathbf{5 0}} \\
(\boldsymbol{\mu M})\end{array}$ & $\begin{array}{l}\text { Combination } \\
\text { Index }(\mathbf{C I})\end{array}$ & Dose Reduction Index (DRI) \\
\hline $\begin{array}{l}\text { Curcumin } \\
\text { ar-turmerone }\end{array}$ & 20 & 20 & & \\
$\begin{array}{l}\text { Cur }+a \text { r-tur } \\
(\text { ratio }=1: 14)^{\mathrm{b}}\end{array}$ & $0.16+2.15$ & 275 & 0.01 & $\begin{array}{l}\text { Curcumin: } 109 \\
\text { ar-turmerone: } 311 \\
\text { Curcumin: } 23 \\
\text { ar-turmerone: } 3563\end{array}$ \\
$\begin{array}{l}\text { Cur }+a \text { r-tur } \\
(\text { ratio }=4: 1)^{\mathrm{c}}\end{array}$ & $0.63+0.16$ & & 0.04 & \\
\hline $\begin{array}{l}\text { Curcumin } \\
\text { Coptisine }\end{array}$ & 20 & 20 & & $\begin{array}{l}\text { Curcumin: } 70 \\
\text { Coptisine: } 42\end{array}$ \\
$\begin{array}{l}\text { Cur }+ \text { Cop } \\
(\text { ratio }=1: 4)^{\mathrm{b}}\end{array}$ & 80 & 80 & 0.03 & \\
\hline
\end{tabular}

\begin{tabular}{lcllc}
\hline $\begin{array}{l}\text { Isolated herbal extracts } \\
\text { and combinations }\end{array}$ & $\begin{array}{l}\text { Minimum } \\
\text { Effective Dose } \\
(\boldsymbol{\mu g} / \mathbf{m l})^{\mathbf{a}}\end{array}$ & $\begin{array}{l}\mathbf{I C}_{\mathbf{5 0}} \\
(\boldsymbol{\mu g} / \mathbf{m l})\end{array}$ & $\begin{array}{l}\text { Combination } \\
\mathbf{I n d e x}(\mathbf{C I})\end{array}$ & Dose Reduction Index (DRI) \\
\hline $\begin{array}{l}\text { Chinese Goldthread } \\
\text { Turmeric }\end{array}$ & - & - & & - \\
$\quad$ Chinese GT + Tur & 70 & 70 & - & - \\
\hline
\end{tabular}

${ }^{a}$ Concentration derived from the dose-response curves where NF- $\kappa$ B transcription was significantly inhibited (p<0.05). ${ }^{b}$ Ratio based on $\mathrm{IC}_{50}$ values. ${ }^{\mathrm{c}}$ Ratio based on relative amounts in turmeric. Abbreviations: Cur, curcumin; ar-tur, ar-turmerone; Cop, coptisine; Chinese GT, Chinese Goldthread; Tur, turmeric.

Inter-herbal comparison of phytonutrients (coptisine with curcumin) on TNF $\alpha$-stimulated NF-кB transcriptional activity: Berberine, just like Chinese goldthread, did not reduce NF- $\kappa \mathrm{B}$ transcriptional activity using concentrations up to $100 \mu \mathrm{M}$ (Fig. 4A). In an effort to explain, in part, the inter-herbal synergism between Chinese goldthread and turmeric, coptisine from Chinese goldthread and curcumin from turmeric were evaluated for synergy (Table 5). To determine the effects on $\mathrm{NF}-\kappa \mathrm{B}$ transcriptional activity with the combination, cells were treated with curcumin plus coptisine with serial dilutions from concentrations equivalent to their $\mathrm{IC}_{50}$ values $(20 \mu \mathrm{M}: 80 \mu \mathrm{M})$ to nanomolar concentrations while maintaining the same ratio. The combination of curcumin plus coptisine reduced NF- $\kappa \mathrm{B}$ transcriptional activity in a dosedependent manner. CI and DRI values were generated for minimum effective concentrations. 
The combination of curcumin and coptisine was highly synergistic in inhibiting NF- $\kappa \mathrm{B}$ transcriptional activity at these levels, where the CI was equal to 0.03 , and the DRIs being 70 and 42 when combined at the minimum effective concentrations $(0.31 \mu \mathrm{M}+1.25 \mu \mathrm{M})$ (Table 5).

\section{DISCUSSION:}

It has been proposed that traditional medicines from various cultures (i.e., Traditional Chinese Medicine) provide effective remedies due to their combinations of herbals, but there is a challenge in establishing a rationale for their superior therapeutic value compared with using isolated bioactives [66]. There is growing evidence that the benefits of combinations of essential and non-essential nutritives lie in their synergy and multiple targets of action [67]. This concept is presented in several reviews describing the lack of concordance between observational studies of bioactives compared with the foods from which the bioactives are derived (i.e., the impact of $\beta$-carotene versus foods that contain $\beta$-carotene on the risk of lung cancer) $[3,67]$.

The mechanisms of the anticancer effects of berberine, curcumin and their herbs from which they are derived have been extensively studied, where they have been shown to modulate cancer cells to induce cell-cycle arrest, cellular apoptosis and inhibition of cell invasion and metastasis. Multiple signaling pathways are known to be affected (including cyclin D, caspase-3, NF- $\mathrm{B}$, PI3 kinase, TNF- $\alpha$, COX-2, MMP-9, etc.) and are well-documented [2, 13, 21-23, 68-71]. Thus, it is not necessary for us to duplicate these mechanistic studies. The aim of this paper was not to revisit the established mechanisms of the anticancer effects of these bioactives, but to assess the synergistic effect between bioactives and compare them to the herbs from which they are derived.

It has been suggested that synergy of polyherbals is related to their multiple targets of action, their coordinated impact on bioavailability, and their collective ability to minimize/neutralize adverse side effects [72]. Furthermore, while many bioactives from botanicals have the same targets [73], it is not always clear whether the mechanisms modifying these targets are similar. Because of our ability to demonstrate the combinations used in this study function synergistically (and not additively), these data suggest while some mechanisms may overlap, others involve biological convergence (modifying a biological outcome, such as cell proliferation, via several pathways) and biochemical convergence (modifying a biochemical pathway, such as NF- $\mathrm{B}$ transcriptional activity, via several mechanisms).

Also important is the concept that the combination of compounds could sufficiently lower the effective dose/concentration when compared with the individual compounds, and similarly, the ability of the combination of herbs to lower the effective dose/concentration when compared with individual herbs or individual bioactives derived from the herbs. If this effective dose/concentration can be sufficiently lowered, there is a better chance that it could have biological meaning, i.e., shifting the effective levels from micromolar to nanomolar concentrations. For most underivatized bioactive phytonutrients, their effective concentrations on cells in culture are typically between 20-100 $\mu \mathrm{M}$ (see Table 1) [1], while the total plasma/serum concentrations (derivatized and underivatized) are typically two to three orders of magnitude lower following oral dosing (see Tables 1 and 2) [74-76].

Investigations in the chemopreventative effects of phytonutrients are not new, but confirming the concept that effectiveness of the botanicals from which these phytonutrients are 
derived, particularly through dose-reduction, may be superior because the synergy of action has been poorly explored. To quantitate this kind of interaction, we used the Chou-Talalay method of analysis [65]. This method can differentiate between synergy, additive effects and antagonism of combinations of agents. It is based on the use of a constant ratio of components through a variety of concentrations (i.e., serial dilutions) while monitoring a single end point (in our case cell proliferation or promoter activation). This computerized model establishes the CI (combination index) to determine the type of interaction, and the DRI (dose-reduction index) represents the magnitude of the dose reduction as a result of the combination for a given dose.

These data are typically generated using ratios of the $\mathrm{IC}_{50}$ values from dose-response curves generated for each individual agent and are presented in each of the tables. Data can also be generated, and was presented in the tables, using concentrations that approach physiological relevance where cell growth was still significantly inhibited. The DRI is important at physiologically relevant concentrations (those plasma/serum concentrations following an oral dose) to establish potential therapeutic value. Because individual phytonutrients within the same botanical (what we refer to as "companion compounds") exist in ratios that may be different from the $\mathrm{IC}_{50}$ values, we also ran a parallel set of experiments using those ratios for biological relevance. For example, the $\mathrm{IC}_{50}$ values for berberine and coptisine are $30 \mu \mathrm{M}$ and $85 \mu \mathrm{M}$, respectively, for a ratio of 1:2.8, but in Chinese goldthread these two compounds exist in a ratio closer to 5:1. The DRI can tell us to what extent one compound can enhance the effectiveness of another compound at a given ratio and dose compared with the compound alone [64].

This study systematically demonstrates that the enhanced effects of herbal extracts compared with individual bioactives found in those extracts may be explained by the synergy of action of the companion compounds found within that extract. When the extract of turmeric was compared with curcumin and the extract of Chinese goldthread compared with berberine, the dose response curves shifted to the left suggesting companion compounds within the extracts could be responsible for this shift by acting in synergy. This was confirmed by establishing the synergy (CI values <1) between companion bioactives from the same extract (i.e., curcumin plus ar-turmerone from turmeric, and berberine plus coptisine from Chinese goldthread).

In addition, this study further supports the concept that the synergy observed by combining two different herbal extracts could, in part, be explained by their synergistic action and due, in part, to the synergistic action of the combination of individual bioactives uniquely derived from these different sources. This is easily illustrated by comparing our previous results with our current results on the ability of Chinese goldthread and turmeric to inhibit proliferation of CWR22Rv1 cells (see Supplemental Figure 1). Chinese goldthread and turmeric, when isolated from a polyherbal mixture, were unable to inhibit cell proliferation at doses of $4.1 \mu \mathrm{g} / \mathrm{ml}$ and $11.3 \mu \mathrm{g} / \mathrm{ml}$, respectively, while our current data demonstrates inhibition of proliferation was observed at doses as low as $1.1 \mu \mathrm{g} / \mathrm{ml}$ and $0.5 \mu \mathrm{g} / \mathrm{ml}$, respectively, when used in combination (Table 3). It is believed that this synergistic effect is due, in part, to the combinations of bioactives unique to each of the extracts. When berberine (from Chinese goldthread) was combined with curcumin (from turmeric), the CI value demonstrated strong synergism. This supports the concept of improved effectiveness with targeted combinations of botanicals.

Our previous studies investigated the mechanisms of a polyherbal mixture containing Chinese goldthread and turmeric on the inhibition of castrate-resistant $\mathrm{PCa}$ in vitro and in vivo 
[7-9]. These inhibitory effects also included mechanisms involving TNF $\alpha$-induced cell proliferation (See Supplemental Figure 2). TNF $\alpha$ signals through NF- $\kappa B$. As a follow-up, this study helps to better define the actions of two of the components in the polyherbal mixture, Chinese goldthread and turmeric, on this signaling pathway. Turmeric and curcumin inhibited NF-kB promoter activity, but Chinese goldthread and berberine were ineffective. Similar to our results, curcumin has been reported by others to inhibit NF- $\mathrm{BB}$ transcriptional activity at similar concentrations observed in this study $(\sim 20 \mu \mathrm{M})$ [77-82]. In contrast, Chinese goldthread and berberine did not inhibit NF- $\mathrm{kB}$ transcriptional activity in this study, and others report similar results with berberine [83, 84]. Interestingly, coptisine, a component of Chinese goldthread, inhibited NF- $\kappa B$ transcriptional activity, but these levels were much higher $\left(\mathrm{IC}_{50}=70 \mu \mathrm{M}\right)$ than what could be achieved as a component of Chinese Goldthread, partially explaining why Chinese goldthread was ineffective. Interestingly, when curcumin was used in combination with the least active bioactives (i.e., coptisine and ar-turmerone), curcumin enhanced their effectiveness 32 and 3563 fold, respectively. In addition, an ineffective Chinese goldthread lowered the minimum effective dose of turmeric 8 fold (a CI value could not be determined due to the lack of a dose response with Chinese goldthread).

Importantly, these data suggest that even when bioactives appear to have little or no activity, they may still act synergistically with other bioactives when used in combination, underscoring the concepts of biological and biochemical convergence. In addition, our data demonstrate that these actions of synergy may be concentration dependent. The use of concentrations higher than the $\mathrm{IC}_{50}$ values (i.e., $\mathrm{IC}_{90}$ ) for the combinations can act in a synergistic manner; however, many times this is not the case. In many instances, the $\mathrm{CI}$ values are $>1$ (antagonism) at concentrations higher than the $\mathrm{IC}_{50}$ value, but $<1$ (synergy) for concentrations lower than the $\mathrm{IC}_{50}$, (see Supplemental Table 1), underscoring the importance of concentrations used in studies.

\section{CONCLUSIONS:}

In summary, most of today's cancers are influenced by our environment, particularly by the botanicals we eat (i.e., herbs, fruits, vegetables). The major source of bioactive phytonutrients is from these foods. To understand the impact of their consumption, our objective was to investigate the concept that the combination of bioactives in botanicals is potentially far more effective than an individual bioactive in isolation. Our data is proof-of-principle that combinations of companion bioactives from the same source and bioactives from different sources act synergistically, providing some evidence that combinations found in botanicals (and foods) have advantages over isolated bioactives. Even compounds with poor efficacy can become more biologically active in the presence of companion compounds. These advantages translate into effective doses that are more physiologic.

List of abbreviations: ber, berberine; cop, coptisine; CI, combination index; cur, curcumin; DRI, dose reduction index; GT, goldthread; tur, turmeric;

Competing interests: The following authors have no conflicts of interest: J. Whelan, Y. Zhao, J. Jason Collier and E-Chu Huang. No competing interests exist regarding interpretation of the data or presentation of information. There are no personal or financial relationships with other people 
or organizations or any financial/non-financial competing interests that influenced any aspect of the research or the writing of the manuscript.

Authors' information: Y. Zhao conducted most of the experiments with collaborative research support from E.-C. Huang and J. J. Collier. J. Whelan and Y. Zhao designed the experiments with input from J.J. Collier. All authors were involved in writing the manuscript.

Acknowledgements: This work was supported by the Tennessee Agricultural Experiment Station (JW), University of Tennessee, Knoxville, TN 37996.

\section{REFERENCES:}

1. Link A, Balaguer F, Goel A: Cancer chemoprevention by dietary polyphenols: promising role for epigenetics. Biochem Pharmacol 2010;80:1771-1792.

2. Sun Y, Xun K, Wang Y, Chen X: A systematic review of the anticancer properties of berberine, a natural product from Chinese herbs. Anticancer Drugs 2009;20:757-769.

3. Meyskens FL, Jr., Szabo E: Diet and cancer: the disconnect between epidemiology and randomized clinical trials. Cancer Epidemiol Biomarkers Prev 2005;14:1366-1369.

4. World Cancer Research Fund/American Institute for Cancer Research: Food, nutrition, physical activity and the prevention of cancer:A global perspective; Washington, DC, American Institute for Cancer Research, 2007.

5. Kushi LH, Doyle C, McCullough M, Rock CL, Demark-Wahnefried W, Bandera EV, Gapstur S, Patel AV, Andrews K, Gansler T: American Cancer Society Guidelines on nutrition and physical activity for cancer prevention: reducing the risk of cancer with healthy food choices and physical activity. CA Cancer J Clin 2012;62:30-67.

6. Sramkoski RM, Pretlow TG, Giaconia JM, Pretlow TP, Schwartz S, Sy MS, Marengo SR, Rhim JS, Zhang D, Jacobberger JW: A new human prostate carcinoma cell line, 22Rv1. In Vitro Cell Dev Biol Anim 1999;35:403-409.

7. Huang E-C, Chen G, Baek SJ, McEntee MF, Biggerstaff JP, Collier JJ, Whelan J: Zyflamend® Reduces the Expression of Androgen Receptor and Insulin-like Growth Factor Receptor, Biomarkers of Cancer Relapse, in a Model of Castrate-Resistant Prostate Cancer. Nutr Cancer 2011;63:1287-1296.

8. Huang E-C, Zhao YCG, Baek SJ, McEntee MF, Minkin S, Biggerstaff JP, Whelan J: Zyflamend, a polyherbal mixture, down regulates class I and class II histone deacetylases and increases p21 levels in castrate-resistant prostate cancer cells. BMC Complement Altern med 2014;14:68.

9. Huang E-C, McEntee MF, Whelan J: Zyflamend, a combination of herbal extracts, attenuates tumor growth in murine xenograph models of prostate cancer. Nutr Cancer 2011;64:749-760.

10. Thomas P, Smart TG: HEK293 cell line: a vehicle for the expression of recombinant proteins. J Pharmacol Toxicol Methods 2005;51:187-200.

11. Burke SJ, Collier JJ: The gene encoding cyclooxygenase-2 is regulated by IL-1beta and prostaglandins in 832/13 rat insulinoma cells. Cell Immunol 2011;271:379-384. 
12. Collins RA: A ten-year audit of traditional Chinese medicine and other natural product research published in the Chinese Medical Journal (2000-2009). Chin Med J (Engl ) 2011;124:1401-1408.

13. Tang J, Feng Y, Tsao S, Wang N, Curtain R, Wang Y: Berberine and Coptidis rhizoma as novel antineoplastic agents: a review of traditional use and biomedical investigations. J Ethnopharmacol 2009;126:5-17.

14. Liu J, He C, Zhou K, Wang J, Kang JX: Coptis extracts enhance the anticancer effect of estrogen receptor antagonists on human breast cancer cells. Biochem Biophys Res Commun 2009;378:174-178.

15. Wang H, Zhang F, Ye F, Ma Y, Zhang DY: The effect of coptis chinensis on the signaling network in the squamous carcinoma cells. Front Biosci (Elite Ed) 2011;3:326-340.

16. Auyeung KK, Ko JK: Coptis chinensis inhibits hepatocellular carcinoma cell growth through nonsteroidal anti-inflammatory drug-activated gene activation. Int $\mathrm{J}$ Mol Med 2009;24:571-577.

17. Lin CC, Ng LT, Hsu FF, Shieh DE, Chiang LC: Cytotoxic effects of Coptis chinensis and Epimedium sagittatum extracts and their major constituents (berberine, coptisine and icariin) on hepatoma and leukaemia cell growth. Clin Exp Pharmacol Physiol 2004;31:6569.

18. Kamath S, Skeels M, Pai A: Significant differences in alkaloid content of Coptis chinensis (Huanglian), from its related American species. Chin Med 2009;4:17.

19. Chen J, Wang F, Liu J, Lee FS, Wang X, Yang H: Analysis of alkaloids in Coptis chinensis Franch by accelerated solvent extraction combined with ultra performance liquid chromatographic analysis with photodiode array and tandem mass spectrometry detections. Anal Chim Acta 2008;613:184-195.

20. Choi MS, Oh JH, Kim SM, Jung HY, Yoo HS, Lee YM, Moon DC, Han SB, Hong JT: Berberine inhibits p53-dependent cell growth through induction of apoptosis of prostate cancer cells. Int J Oncol 2009;34:1221-1230.

21. Li J, Cao B, Liu X, Fu X, Xiong Z, Chen L, Sartor O, Dong Y, Zhang H: Berberine suppresses androgen receptor signaling in prostate cancer. Mol Cancer Ther 2011;10:1346-1356.

22. Schaffer M, Schaffer PM, Zidan J, Bar SG: Curcuma as a functional food in the control of cancer and inflammation. Curr Opin Clin Nutr Metab Care 2011;14:588-597.

23. Wilken R, Veena MS, Wang MB, Srivatsan ES: Curcumin: A review of anti-cancer properties and therapeutic activity in head and neck squamous cell carcinoma. Mol Cancer 2011;10:12.

24. Gupta SC, Sung B, Kim JH, Prasad S, Li S, Aggarwal BB: Multitargeting by turmeric, the golden spice: From kitchen to clinic. Mol Nutr Food Res 2012.

25. Pozharitskaya ON, Ivanova SA, Shikov AN, Makarov VG: Separation and free radicalscavenging activity of major curcuminoids of Curcuma longa using HPTLC-DPPH method. Phytochem Anal 2008;19:236-243.

26. Das T, Sa G, Saha B, Das K: Multifocal signal modulation therapy of cancer: ancient weapon, modern targets. Mol Cell Biochem 2010;336:85-95. 
27. Teiten MH, Gaascht F, Cronauer M, Henry E, Dicato M, Diederich M: Anti-proliferative potential of curcumin in androgen-dependent prostate cancer cells occurs through modulation of the Wingless signaling pathway. Int J Oncol 2011;38:603-611.

28. Gupta SC, Sung B, Kim JH, Prasad S, Li S, Aggarwal BB: Multitargeting by turmeric, the golden spice: From kitchen to clinic. Mol Nutr Food Res 2012.

29. Singh G, Kapoor IP, Singh P, de Heluani CS, de Lampasona MP, Catalan CA: Comparative study of chemical composition and antioxidant activity of fresh and dry rhizomes of turmeric (Curcuma longa Linn.). Food Chem Toxicol 2010;48:1026-1031.

30. Priya R, Prathapan A, Raghu KG, Menon AN: Chemical composition and in vitro antioxidant potential of essential oil isolated from Curcuma longa L. leaves. Asian Pac J Trop Med 2012;5:S695-S699.

31. Duke JA: Handbook of phytochemical constituents of GRAS herbs and other economic plants. Boca Raton, FL, CRC Press, 1992.

32. Ji M, Choi J, Lee J, Lee Y: Induction of apoptosis by ar-turmerone on various cell lines. Int J Mol Med 2004;14:253-256.

33. Lin X, Ji S, Qiao X, Hu H, Chen N, Dong Y, Huang Y, Guo D, Tu P, Ye M: Density Functional Theory Calculations in Stereochemical Determination of Terpecurcumins J-W, Cytotoxic Terpene-Conjugated Curcuminoids from Curcuma longa L. J Org Chem 2013;78:11835-11848.

34. Park SY, Kim YH, Kim Y, Lee SJ: Aromatic-turmerone attenuates invasion and expression of MMP-9 and COX-2 through inhibition of NF-kappaB activation in TPAinduced breast cancer cells. J Cell Biochem 2012;113:3653-3662.

35. Yue GG, Chan BC, Hon PM, Lee MY, Fung KP, Leung PC, Lau CB: Evaluation of in vitro anti-proliferative and immunomodulatory activities of compounds isolated from Curcuma longa. Food Chem Toxicol 2010;48:2011-2020.

36. Cheng SB, Wu LC, Hsieh YC, Wu CH, Chan YJ, Chang LH, Chang CM, Hsu SL, Teng $\mathrm{CL}, \mathrm{Wu}$ CC: Supercritical carbon dioxide extraction of aromatic turmerone from Curcuma longa Linn. induces apoptosis through reactive oxygen species-triggered intrinsic and extrinsic pathways in human hepatocellular carcinoma HepG2 cells. J Agric Food Chem 2012;60:9620-9630.

37. Jin RJ, Lho Y, Connelly L, Wang Y, Yu X, Saint JL, Case TC, Ellwood-Yen K, Sawyers CL, Bhowmick NA, Blackwell TS, Yull FE, Matusik RJ: The nuclear factor-kappaB pathway controls the progression of prostate cancer to androgen-independent growth. Cancer Res 2008;68:6762-6769.

38. Nadiminty N, Lou W, Sun M, Chen J, Yue J, Kung HJ, Evans CP, Zhou Q, Gao AC: Aberrant activation of the androgen receptor by NF-kappaB2/p52 in prostate cancer cells. Cancer Res 2010;70:3309-3319.

39. Gupta SC, Sundaram C, Reuter S, Aggarwal BB: Inhibiting NF-kappaB activation by small molecules as a therapeutic strategy. Biochim Biophys Acta 2010;1799:775-787.

40. Aggarwal BB, Shishodia S: Suppression of the nuclear factor-kappaB activation pathway by spice-derived phytochemicals: reasoning for seasoning. Ann $\mathrm{N}$ Y Acad Sci 2004;1030:434-441. 
41. Howells LM, Moiseeva EP, Neal CP, Foreman BE, Andreadi CK, Sun YY, Hudson EA, Manson MM: Predicting the physiological relevance of in vitro cancer preventive activities of phytochemicals. Acta Pharmacol Sin 2007;28:1274-1304.

42. Pal A, Sung B, Bhanu Prasad BA, Schuber PT, Jr., Prasad S, Aggarwal BB, Bornmann WG: Curcumin glucuronides: Assessing the proliferative activity against human cell lines. Bioorg Med Chem 2013.

43. Refaat A, Abdelhamed S, Yagita H, Inoue H, Yokoyama S, Hayakawa Y, Saiki I: Berberine enhances tumor necrosis factor-related apoptosis-inducing ligand-mediated apoptosis in breast cancer. Oncol Lett 2013;6:840-844.

44. Tanabe H, Suzuki H, Nagatsu A, Mizukami H, Ogihara Y, Inoue M: Selective inhibition of vascular smooth muscle cell proliferation by coptisine isolated from Coptis rhizoma, one of the crude drugs composing Kampo medicines Unsei-in. Phytomedicine 2006;13:334-342.

45. Yi J, Ye X, Wang D, He K, Yang Y, Liu X, Li X: Safety evaluation of main alkaloids from Rhizoma Coptidis. J Ethnopharmacol 2013;145:303-310.

46. Du WZ, Feng Y, Wang XF, Piao XY, Cui YQ, Chen LC, Lei XH, Sun X, Liu X, Wang HB, Li XF, Yang DB, Sun Y, Zhao ZF, Jiang T, Li YL, Jiang CL: Curcumin Suppresses Malignant Glioma Cells Growth and Induces Apoptosis by Inhibition of SHH/GLI1 Signaling Pathway in Vitro and Vivo. CNS Neurosci Ther 2013;19:926-936.

47. Lin CC, Ng LT, Hsu FF, Shieh DE, Chiang LC: Cytotoxic effects of Coptis chinensis and Epimedium sagittatum extracts and their major constituents (berberine, coptisine and icariin) on hepatoma and leukaemia cell growth. Clin Exp Pharmacol Physiol 2004;31:6569.

48. Hung CM, Su YH, Lin HY, Lin JN, Liu LC, Ho CT, Way TD: Demethoxycurcumin Modulates Prostate Cancer Cell Proliferation via AMPK-Induced Down-regulation of HSP70 and EGFR. J Agric Food Chem 2012.

49. Tsui KH, Feng TH, Lin CM, Chang PL, Juang HH: Curcumin blocks the activation of androgen and interlukin- 6 on prostate-specific antigen expression in human prostatic carcinoma cells. J Androl 2008;29:661-668.

50. Hong JH, Ahn KS, Bae E, Jeon SS, Choi HY: The effects of curcumin on the invasiveness of prostate cancer in vitro and in vivo. Prostate Cancer Prostatic Dis 2006;9:147-152.

51. Jiang M, Huang O, Zhang X, Xie Z, Shen A, Liu H, Geng M, Shen K: Curcumin induces cell death and restores tamoxifen sensitivity in the antiestrogen-resistant breast cancer cell lines MCF-7/LCC2 and MCF-7/LCC9. Molecules 2013;18:701-720.

52. Lee Y: Activation of apoptotic protein in U937 cells by a component of turmeric oil. BMB Rep 2009;42:96-100.

53. Colombo ML, Bugatti C, Mossa A, Pescalli N, Piazzoni L, Pezzoni G, Menta E, Spinelli S, Johnson F, Gupta RC, Dasaradhi L: Cytotoxicity evaluation of natural coptisine and synthesis of coptisine from berberine. Farmaco 2001;56:403-409.

54. Sharma RA, Euden SA, Platton SL, Cooke DN, Shafayat A, Hewitt HR, Marczylo TH, Morgan B, Hemingway D, Plummer SM, Pirmohamed M, Gescher AJ, Steward WP: Phase I clinical trial of oral curcumin: biomarkers of systemic activity and compliance. Clin Cancer Res 2004;10:6847-6854. 
55. Ringman JM, Frautschy SA, Teng E, Begum AN, Bardens J, Beigi M, Gylys KH, Badmaev V, Heath DD, Apostolova LG, Porter V, Vanek Z, Marshall GA, Hellemann G, Sugar C, Masterman DL, Montine TJ, Cummings JL, Cole GM: Oral curcumin for Alzheimer's disease: tolerability and efficacy in a 24-week randomized, double blind, placebo-controlled study. Alzheimers Res Ther 2012;4:43.

56. Sasaki H, Sunagawa Y, Takahashi K, Imaizumi A, Fukuda H, Hashimoto T, Wada H, Katanasaka Y, Kakeya H, Fujita M, Hasegawa K, Morimoto T: Innovative preparation of curcumin for improved oral bioavailability. Biol Pharm Bull 2011;34:660-665.

57. Lao CD, Ruffin MT, Normolle D, Heath DD, Murray SI, Bailey JM, Boggs ME, Crowell $\mathrm{J}$, Rock CL, Brenner DE: Dose escalation of a curcuminoid formulation. BMC Complement Altern med 2006;6:10.

58. Cheng AL, Hsu CH, Lin JK, Hsu MM, Ho YF, Shen TS, Ko JY, Lin JT, Lin BR, MingShiang W, Yu HS, Jee SH, Chen GS, Chen TM, Chen CA, Lai MK, Pu YS, Pan MH, Wang YJ, Tsai CC, Hsieh CY: Phase I clinical trial of curcumin, a chemopreventive agent, in patients with high-risk or pre-malignant lesions. Anticancer Res 2001;21:28952900.

59. Garcea G, Jones DJ, Singh R, Dennison AR, Farmer PB, Sharma RA, Steward WP, Gescher AJ, Berry DP: Detection of curcumin and its metabolites in hepatic tissue and portal blood of patients following oral administration. Br J Cancer 2004;90:1011-1015.

60. Sharma RA, McLelland HR, Hill KA, Ireson CR, Euden SA, Manson MM, Pirmohamed M, Marnett LJ, Gescher AJ, Steward WP: Pharmacodynamic and pharmacokinetic study of oral Curcuma extract in patients with colorectal cancer. Clin Cancer Res 2001;7:18941900.

61. Shoba G, Joy D, Joseph T, Majeed M, Rajendran R, Srinivas PS: Influence of piperine on the pharmacokinetics of curcumin in animals and human volunteers. Planta Med 1998;64:353-356.

62. Klickovic U, Doberer D, Gouya G, Aschauer S, Weisshaar S, Storka A, Bilban M, Wolzt M: Human pharmacokinetics of high dose oral curcumin and its effect on heme oxygenase-1 expression in healthy male subjects. Biomed Res Int 2014;2014:458592.

63. Huang E-C, McEntee MF, Whelan J: Zyflamend, a combination of herbal extracts, attenuates tumor growth in murine xenograph models of prostate cancer. Nutr Cancer 2011;64:749-760.

64. Chou TC: Drug combination studies and their synergy quantification using the ChouTalalay method. Cancer Res 2010;70:440-446.

65. Chou TC: Theoretical basis, experimental design, and computerized simulation of synergism and antagonism in drug combination studies. Pharmacol Rev 2006;58:621-681.

66. Wagner H: Synergy research: approaching a new generation of phytopharmaceuticals. Fitoterapia 2011;82:34-37.

67. Gibson TM, Ferrucci LM, Tangrea JA, Schatzkin A: Epidemiological and clinical studies of nutrition. Semin Oncol 2010;37:282-296.

68. Lin JK: Molecular targets of curcumin. Adv Exp Med Biol 2007;595:227-243. 
69. Yu S, Shen G, Khor TO, Kim JH, Kong AN: Curcumin inhibits Akt/mammalian target of rapamycin signaling through protein phosphatase-dependent mechanism. Mol Cancer Ther 2008;7:2609-2620.

70. Beevers CS, Chen L, Liu L, Luo Y, Webster NJ, Huang S: Curcumin disrupts the Mammalian target of rapamycin-raptor complex. Cancer Res 2009;69:1000-1008.

71. Gupta SC, Sung B, Kim JH, Prasad S, Li S, Aggarwal BB: Multitargeting by turmeric, the golden spice: From kitchen to clinic. Mol Nutr Food Res 2012.

72. Wagner H, Ulrich-Merzenich G: Synergy research: approaching a new generation of phytopharmaceuticals. Phytomedicine 2009;16:97-110.

73. Manson MM: Inhibition of survival signalling by dietary polyphenols and indole-3carbinol. Eur J Cancer 2005;41:1842-1853.

74. Zick SM, Djuric Z, Ruffin MT, Litzinger AJ, Normolle DP, Alrawi S, Feng MR, Brenner DE: Pharmacokinetics of 6-gingerol, 8-gingerol, 10-gingerol, and 6-shogaol and conjugate metabolites in healthy human subjects. Cancer Epidemiol Biomarkers Prev 2008;17:19301936.

75. Del RD, Borges G, Crozier A: Berry flavonoids and phenolics: bioavailability and evidence of protective effects. Br J Nutr 2010;104 Suppl 3:S67-S90.

76. Anand P, Kunnumakkara AB, Newman RA, Aggarwal BB: Bioavailability of curcumin: problems and promises. Mol Pharm 2007;4:807-818.

77. Oh SW, Cha JY, Jung JE, Chang BC, Kwon HJ, Lee BR, Kim DY: Curcumin attenuates allergic airway inflammation and hyper-responsiveness in mice through NF-kappaB inhibition. J Ethnopharmacol 2011;136:414-421.

78. Lim JH, Kwon TK: Curcumin inhibits phorbol myristate acetate (PMA)-induced MCP-1 expression by inhibiting ERK and NF-kappaB transcriptional activity. Food Chem Toxicol 2010;48:47-52.

79. Jeong WS, Kim IW, $\mathrm{Hu} \mathrm{R}$, Kong AN: Modulatory properties of various natural chemopreventive agents on the activation of NF-kappaB signaling pathway. Pharm Res 2004;21:661-670.

80. Marin YE, Wall BA, Wang S, Namkoong J, Martino JJ, Suh J, Lee HJ, Rabson AB, Yang CS, Chen S, Ryu JH: Curcumin downregulates the constitutive activity of NF-kappaB and induces apoptosis in novel mouse melanoma cells. Melanoma Res 2007;17:274-283.

81. Chen D, Nie M, Fan MW, Bian Z: Anti-inflammatory activity of curcumin in macrophages stimulated by lipopolysaccharides from Porphyromonas gingivalis. Pharmacology 2008;82:264-269.

82. Hu P, Huang P, Chen MW: Curcumin attenuates cyclooxygenase-2 expression via inhibition of the NF-kappaB pathway in lipopolysaccharide-stimulated human gingival fibroblasts. Cell Biol Int 2013;37:443-448.

83. Dvorak Z, Vrzal R, Maurel P, Ulrichova J: Differential effects of selected natural compounds with anti-inflammatory activity on the glucocorticoid receptor and NF-kappaB in HeLa cells. Chem Biol Interact 2006;159:117-128.

84. Cao M, Wang P, Sun C, He W, Wang F: Amelioration of IFN-gamma and TNF-alphainduced intestinal epithelial barrier dysfunction by berberine via suppression of MLCKMLC phosphorylation signaling pathway. PLoS One 2013;8:e61944. 


\section{SUPPLEMENTAL FIGURES AND TABLES:}

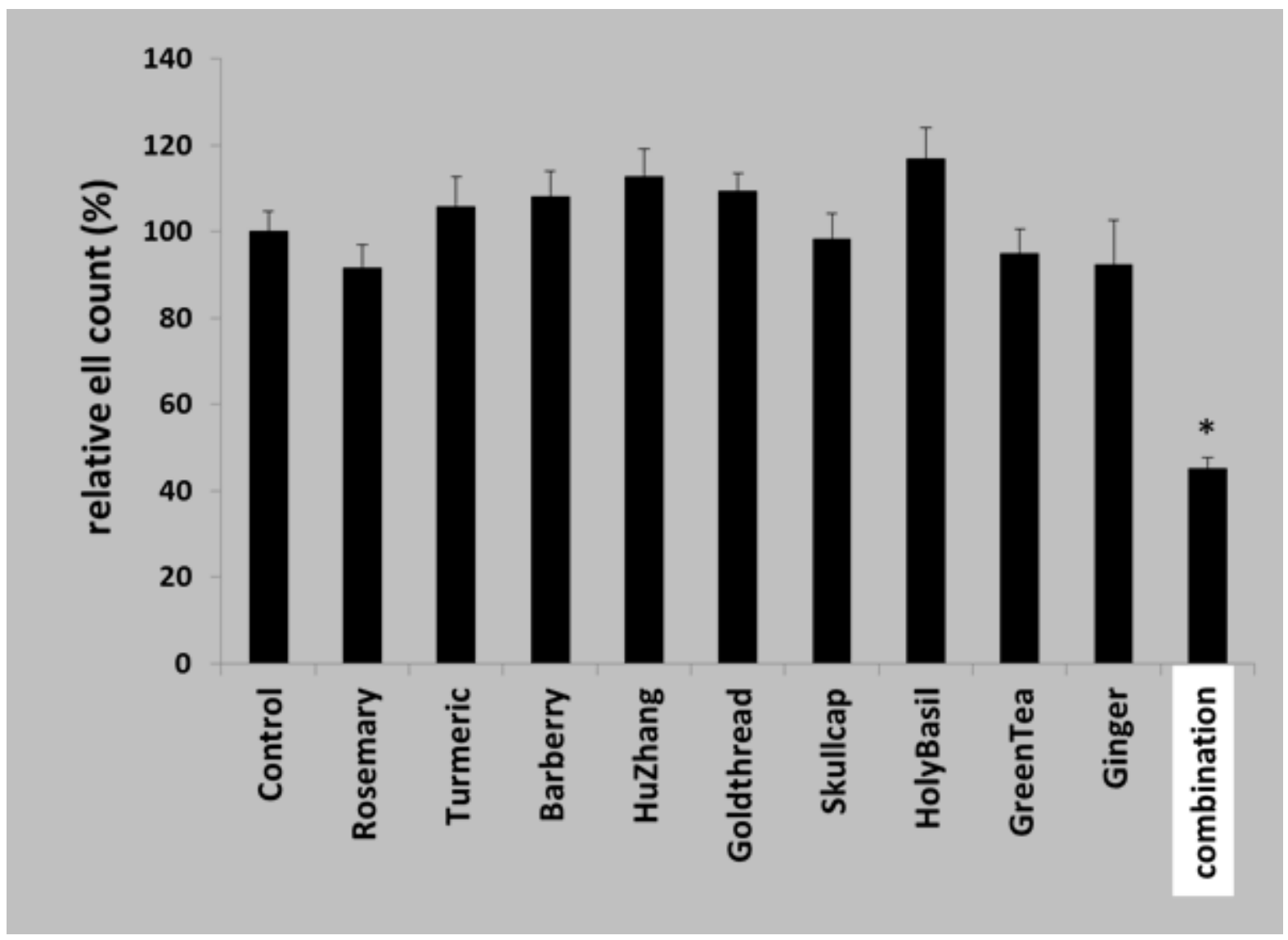

Supplement Figure 1: The effects of individual herbs versus their combination on cell proliferation. CWR22Rv1 cells were treated with individual herbal extracts $(10.2 \mu \mathrm{g} / \mathrm{ml}$ ginger, $15.4 \mu \mathrm{g} / \mathrm{ml}$ rosemary, $11.3 \mu \mathrm{g} / \mathrm{ml}$ turmeric, $4.1 \mu \mathrm{g} / \mathrm{ml}$ Chinese goldthread, 10.2 $\mu \mathrm{g} / \mathrm{ml}$ holy basil, $8.2 \mu \mathrm{g} / \mathrm{ml}$ hu zhang, $4.1 \mu \mathrm{g} / \mathrm{ml}$ barberry, $10.2 \mu \mathrm{g} / \mathrm{ml}$ green tea, $2.0 \mu \mathrm{g} / \mathrm{ml}$ Baikal skullcap) or in combination equivalent to amounts used individually ( $76 \mathrm{ug} / \mathrm{ml}$ ) for $48 \mathrm{hr}$ and cell viability was measured by MTT assay (see "Methods" section of the paper). For more details of the mixture see references 7-9. Treatment with individual herbal extracts did not significantly affect cell viability, whereas their combination significantly reduced cell viability. Data is presented as means $\pm \mathrm{SD}(\mathrm{n}=8)$. Bars with an asterisk $(*)$ are significantly different from the non-treated Control at $\mathrm{p}<0.05$. 


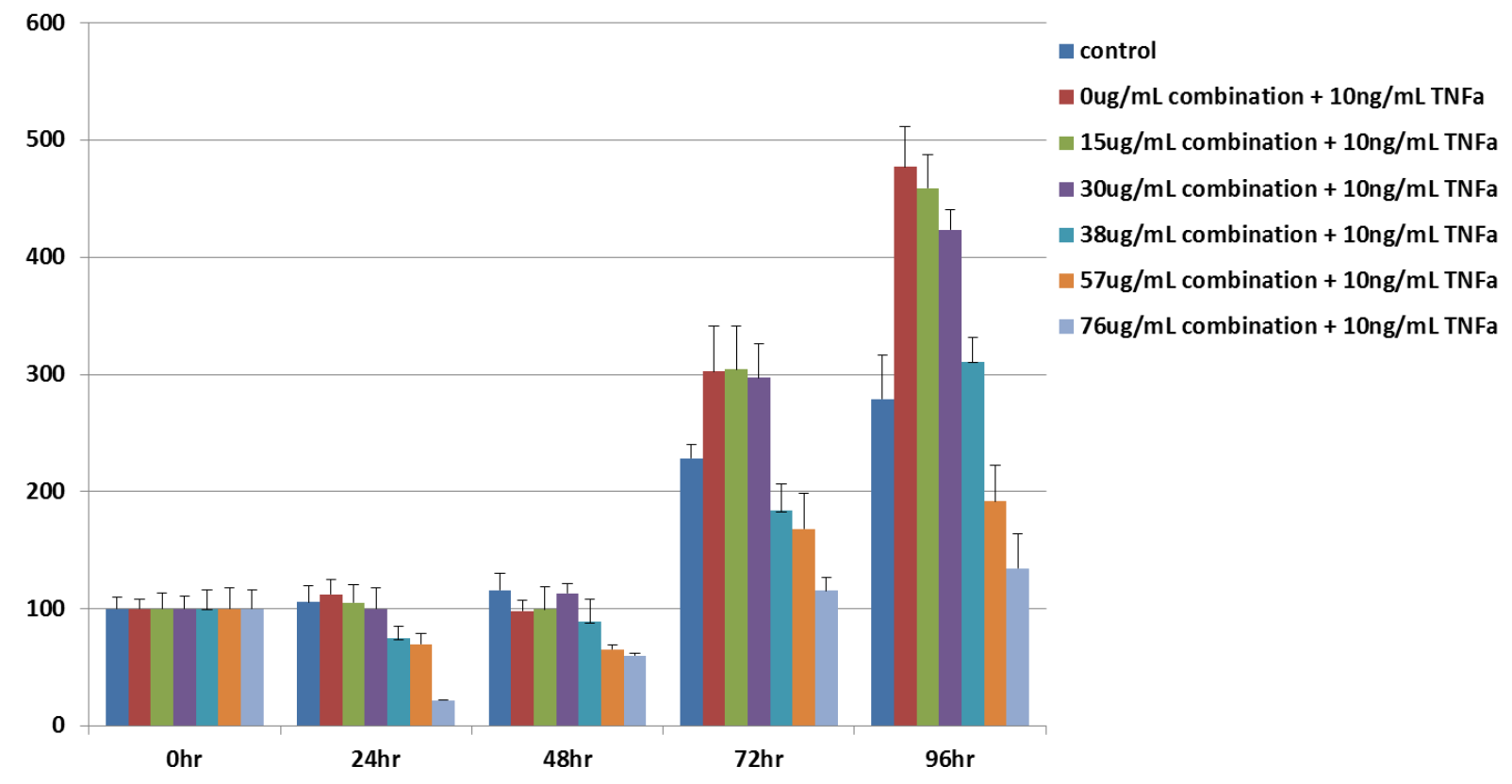

Supplemental Figure 2. CWR22Rv1 cell were treated with a combination of herbal extracts (composition: $10.2 \mu \mathrm{g} / \mathrm{ml}$ ginger, $15.4 \mu \mathrm{g} / \mathrm{ml}$ rosemary, $11.3 \mu \mathrm{g} / \mathrm{ml}$ turmeric, $4.1 \mu \mathrm{g} / \mathrm{ml}$ Chinese goldthread, $10.2 \mu \mathrm{g} / \mathrm{ml}$ holy basil, $8.2 \mu \mathrm{g} / \mathrm{ml}$ hu zhang, $4.1 \mu \mathrm{g} / \mathrm{ml}$ barberry, $10.2 \mu \mathrm{g} / \mathrm{ml}$ green tea, $2.0 \mu \mathrm{g} / \mathrm{ml}$ baikal skullcap) with increasing combined concentrations $(0,15,30,38,57,76 \mathrm{ug} / \mathrm{ml})$ with or without TNF- $\alpha(10 \mathrm{ng} / \mathrm{ml})$ for $0,24,48,72$, and $96 \mathrm{hr}$. For more details of the herbal mixture see references 7-9. Cell viability was measured by MTT assay (see "Methods" section of the paper). TNF- $\alpha$ had a progressive effect on cell proliferation over time and this effect was attenuated in the presence of herbal mixture in a dose-dependent manner. Data is presented as means $\pm \mathrm{SD}(\mathrm{n}=8)$. 
Supplemental Table 1: Dose-effect relationships of Chinese goldthread, turmeric, berberine, coptisine, curcumin and ar-turmerone and their combinations on proliferation of CWR22Rv1 and HEK293 cells and NF- $\mathrm{NB}$ promoter activity.

\begin{tabular}{|c|c|c|c|c|c|c|c|c|c|c|c|c|c|c|c|}
\hline $\begin{array}{l}\text { Compounds / } \\
\text { combinations }\end{array}$ & $\begin{array}{c}\mathrm{Dm} \\
(\mu \mathrm{M})\end{array}$ & $\mathrm{m}$ & $\mathrm{r}$ & $\begin{array}{c}\mathrm{CI} \\
\mathrm{IC}_{25}\end{array}$ & $\begin{array}{c}\mathrm{CI} \\
\mathrm{IC}_{50}\end{array}$ & $\begin{array}{c}\mathrm{CI} \\
\mathrm{IC}_{75}\end{array}$ & $\begin{array}{c}\mathrm{CI} \\
\mathrm{IC}_{90}\end{array}$ & $\begin{array}{l}\text { DRI- } \\
\mathrm{IC}_{25}\end{array}$ & $\begin{array}{l}\text { DRI- } \\
\text { IC }_{50}\end{array}$ & $\begin{array}{l}\text { DRI- } \\
\mathrm{IC}_{75}\end{array}$ & $\begin{array}{l}\text { DRI- } \\
\text { IC }_{90}\end{array}$ & $\begin{array}{l}\text { DRI- } \\
\mathrm{IC}_{25}\end{array}$ & $\begin{array}{l}\text { DRI- } \\
\mathrm{IC}_{50}\end{array}$ & $\begin{array}{l}\text { DRI- } \\
\mathrm{IC}_{75}\end{array}$ & $\begin{array}{l}\text { DRI- } \\
\text { IC }_{90}\end{array}$ \\
\hline \multicolumn{7}{|c|}{ Inhibition of Proliferation using CWR22Rv1 Cells } & & Ber & Ber & Ber & Ber & Cop & Cop & Cop & Cop \\
\hline Berberine & 23.1 & 1.7 & 0.9 & & & & & & & & & & & & \\
\hline Coptisine & 96.7 & 0.8 & 0.9 & & & & & & & & & & & & \\
\hline Ber:Cop (1: 2.8) & 27.2 & 0.6 & 0.8 & 0.2 & 0.5 & 1.5 & 4.7 & 11.8 & 3.3 & 0.9 & 0.1 & 8.4 & 4.8 & 2.7 & 1.6 \\
\hline Ber:Cop $(5: 1)^{b}$ & 25.3 & 1.2 & 0.9 & 0.8 & 0.9 & 1.2 & 1.6 & 1.4 & 1.1 & 0.8 & 0.6 & 14.5 & 22.9 & 36.3 & 57.3 \\
\hline \multicolumn{7}{|c|}{ Inhibition of Proliferation using CWR22Rv1 Cells } & & Cur & Cur & Cur & Cur & ar-T & ar-T & ar-T & ar-T \\
\hline Curcumin & 11.4 & 2.1 & 0.9 & & & & & & & & & & & & \\
\hline ar-turmerone & 328.3 & 0.4 & 0.9 & & & & & & & & & & & & \\
\hline Cur:ar-T $(1: 6.8)^{\mathrm{a}}$ & 13.8 & 1.2 & 0.7 & 0.3 & 0.2 & 0.2 & 0.4 & 10.0 & 6.4 & 4.1 & 2.7 & 6.0 & 27.3 & 124 & 564 \\
\hline Cur:ar-T (4: 1) ${ }^{\mathrm{b}}$ & 4.4 & 1.0 & 0.8 & 0.2 & 0.3 & 0.6 & 1.1 & 6.1 & 3.2 & 1.7 & 0.9 & 99.4 & 371 & 1386 & 5173 \\
\hline \multicolumn{7}{|c|}{\begin{tabular}{|l|l} 
Inhibition of Proliferation using CWR22Rv1 Cells \\
\end{tabular}} & & Ber & Ber & Ber & Ber & Cur & Cur & Cur & Cur \\
\hline Berberine & 23.1 & 1.7 & 0.9 & & & & & & & & & & & & \\
\hline Curcumin & 11.4 & 2.1 & 0.9 & & & & & & & & & & & & \\
\hline Ber:Cur $(1.4: 1)^{\mathrm{a}}$ & 13.8 & 1.2 & 0.7 & 0.5 & 0.6 & 0.7 & 0.9 & 4.8 & 4.3 & 3.9 & 3.5 & 3.9 & 2.9 & 2.1 & 1.6 \\
\hline \multicolumn{7}{|c|}{ Inhibition of Proliferation using CWR22Rv1 Cells } & & $\mathbf{C G}$ & CG & CG & $\mathbf{C G}$ & Tur & Tur & Tur & Tur \\
\hline $\begin{array}{l}\text { Chinese } \\
\text { goldthread }\end{array}$ & 106 & 1.6 & 0.9 & & & & & & & & & & & & \\
\hline Turmeric & 49.6 & 1.8 & 0.8 & & & & & & & & & & & & \\
\hline $\begin{array}{l}\text { Chinese GT: } \\
\text { Tur }(2: 1)^{\mathrm{a}}\end{array}$ & 87.5 & 0.6 & 0.8 & 0.3 & 1.1 & 3.7 & 12 & 5.7 & 1.8 & 0.6 & 0.2 & 5.8 & 1.7 & 0.5 & 0.2 \\
\hline \multicolumn{7}{|c|}{ Inhibition of Proliferation using HEK293 Cells } & & Ber & Ber & Ber & Ber & Cop & Cop & Cop & Cop \\
\hline Berberine & 42.9 & 2.6 & 0.9 & & & & & & & & & & & & \\
\hline Coptisine & 81.9 & 2.8 & 0.9 & & & & & & & & & & & & \\
\hline Ber:Cop $(1: 2.3)^{\mathrm{a}}$ & 51.2 & 2.0 & 0.9 & 0.7 & 0.8 & 0.9 & 1.0 & 3.2 & 2.8 & 2.5 & 2.2 & 2.7 & 2.3 & 2.0 & 1.7 \\
\hline Ber:Cop $(5: 1)^{b}$ & 33.3 & 1.0 & 0.9 & 0.3 & 0.7 & 1.5 & 3.0 & 3.2 & 1.5 & 0.8 & 0.4 & 31.3 & 14.8 & 7.0 & 3.3 \\
\hline \multicolumn{7}{|c|}{ Inhibition of Proliferation using HEK2931 Cells } & & Cur & Cur & Cur & Cur & ar-T & $a r-\mathrm{T}$ & ar-T & ar-T \\
\hline Curcumin & 17.3 & 3.2 & 0.9 & & & & & & & & & & & & \\
\hline ar-turmerone & 400.6 & 1.0 & 0.9 & & & & & & & & & & & & \\
\hline Cur:ar-T (1:6.8) & 100.3 & 1.3 & 0.9 & 0.4 & 0.4 & 0.4 & 0.6 & 10.6 & 6.4 & 4.0 & 2.4 & 3.1 & 4.1 & 5.5 & 2.4 \\
\hline Cur:ar-T $(4: 1)^{\mathrm{b}}$ & 11.1 & 1.5 & 0.8 & 0.4 & 0.5 & 0.8 & 1.1 & 2.9 & 1.9 & 1.3 & 0.9 & 122 & 180 & 267 & 395 \\
\hline \multicolumn{7}{|c|}{ Inhibition of Proliferation using HEK2931 Cells } & & Ber & Ber & Ber & Ber & Cur & Cur & Cur & Cur \\
\hline Berberine & 37.8 & 2.6 & 0.9 & & & & & & & & & & & & \\
\hline Curcumin & 17.2 & 3.2 & 0.9 & & & & & & & & & & & & \\
\hline Ber:Cur $(1.4: 1)^{\mathrm{a}}$ & 18.0 & 1.9 & 0.9 & 0.5 & 0.6 & 0.8 & 0.9 & 3.3 & 2.9 & 2.5 & 2.1 & 4.5 & 3.6 & 2.8 & 2.2 \\
\hline \multicolumn{7}{|c|}{\begin{tabular}{|l} 
Inhibition of Proliferation using HEK2931 Cells \\
\end{tabular}} & & Ber & Ber & Ber & Ber & Cur & Cur & Cur & Cur \\
\hline Chinese & 152 & 2.3 & 0.9 & & & & & & & & & & & & \\
\hline
\end{tabular}




\begin{tabular}{|c|c|c|c|c|c|c|c|c|c|c|c|c|c|c|c|}
\hline \multicolumn{16}{|l|}{ goldthread } \\
\hline Turmeric & 49.3 & 2.9 & 0.8 & & & & & & & & & & & & \\
\hline $\begin{array}{l}\text { Chinese GT: } \\
\text { Tur }(2: 1)^{\mathrm{a}}\end{array}$ & 73.7 & 2.6 & 0.9 & 0.8 & 0.8 & 0.8 & 0.8 & 2.7 & 2.8 & 3.0 & 3.1 & 2.6 & 2.5 & 2.4 & 2.3 \\
\hline \multicolumn{7}{|c|}{$\begin{array}{l}\text { NF-kB Promoter Activity using Transfected HEK293 } \\
\text { Cells }\end{array}$} & & CG & CG & CG & CG & Tur & Tur & Tur & Tur \\
\hline Curcumin & 35.0 & 1.3 & 0.5 & & & & & & & & & & & & \\
\hline ar-turmerone & 1418 & 1.3 & 0.5 & & & & & & & & & & & & \\
\hline Cur:ar-T $(1: 14)$ & - & - & - & - & - & - & - & - & - & - & - & - & - & - & - \\
\hline Cur:ar-T $(4: 1)^{\mathrm{b}}$ & 43 & 0.8 & 0.4 & 0.6 & 0.9 & 1.7 & 2.9 & 1.8 & 1.0 & 0.6 & 0.3 & 273 & 166 & 101 & 61 \\
\hline \multicolumn{7}{|c|}{$\begin{array}{l}\text { NF-кB Promoter Activity using Transfected HEK293 } \\
\text { Cells }\end{array}$} & & Cur & Cur & Cur & Cur & Cop & Cop & Cop & Cop \\
\hline Curcumin & 35.0 & 1.3 & 0.5 & & & & & & & & & & & & \\
\hline Coptisine & 90.3 & 1.1 & 0.6 & & & & & & & & & & & & \\
\hline Cur: Cop $(1: 4)^{\mathrm{a}}$ & 16.2 & 0.7 & 0.8 & 0.1 & 0.2 & 0.4 & 0.7 & 20.5 & 10.8 & 5.7 & 3.0 & 11.6 & 7.0 & 4.2 & 2.5 \\
\hline
\end{tabular}

$\mathrm{D}_{\mathrm{m}}$ : median-effect dose (concentration which inhibits cell growth by $50 \%$ ). m: shape of the doseeffect curves, where $\mathrm{m}=1$, hyperbolic; $\mathrm{m}>1$, sigmoidal; and $\mathrm{m}<1$, flat sigmoidal, respectively. $\mathrm{r}$ : linear correlation coefficient of the median-effect plot (indicates conformity of data). ${ }^{\mathrm{a}}$ Ratio based on $\mathrm{IC}_{50}$ values. ${ }^{\mathrm{b}}$ Ratio based on relative amounts in Chinese goldthread.

Abbreviations: ar-T, ar-turmerone; Ber, berberine; CG, Chinese goldthread; CI, combination index; Cop, coptisine; Cur: curcumin; DRI, dose reduction index. 